\title{
Laboreal
}

Volume $16 \mathrm{~N}^{\circ} 2$ | 2020

Programa de Pesquisa do Curso da Ação

\section{Modelagem teórica da experiência mimética e "Curso de ação" : análise de situações de formação na educação, na saúde e no desporto}

Modelización teórica de la experiencia mimética y "Curso de acción" : análisis de situaciones de formación en enseñanza, salud y deporte

Modélisation théorique de l'expérience mimétique et "Cours d'action" : analyse de situations de formation en enseignement, santé, et sport

Theoretical modeling of the mimetic experience and "Course of action" : analysis of training situations in education, health, and sport

\section{Serge Leblanc, Hélène Bouchot y Mélanie Secheppet}

\section{OpenEdition}

\section{Journals}

\section{Edición electrónica}

URL: http://journals.openedition.org/laboreal/17291

DOI: 10.4000/laboreal.17291

ISSN: 1646-5237

Editor

Universidade do Porto

Referencia electrónica

Serge Leblanc, Hélène Bouchot y Mélanie Secheppet, « Modelagem teórica da experiência mimética e "Curso de ação" : análise de situações de formação na educação, na saúde e no desporto », Laboreal [En línea], Volume 16 №2 | 2020, Publicado el 01 diciembre 2020, consultado el 13 diciembre 2020. URL : http://journals.openedition.org/laboreal/17291; DOI : https://doi.org/10.4000/laboreal.17291

Este documento fue generado automáticamente el 13 diciembre 2020.

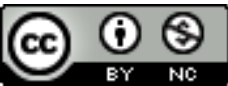

Laboreal está licenciado com uma Licença Creative Commons - Atribuição-NãoComercial 4.0 Internacional. 


\section{Modelagem teórica da experiência mimética e "Curso de ação" : análise de situações de formação na educação, na saúde e no desporto}

Modelización teórica de la experiencia mimética y "Curso de acción": análisis de situaciones de formación en enseñanza, salud y deporte

Modélisation théorique de l'expérience mimétique et "Cours d'action" : analyse de situations de formation en enseignement, santé, et sport

Theoretical modeling of the mimetic experience and "Course of action" : analysis of training situations in education, health, and sport

Serge Leblanc, Hélène Bouchot y Mélanie Secheppet

\section{NOTA DEL EDITOR}

Manuscrito recibido en : 02/03/2020

Aceptado tras peritaje en : $26 / 10 / 2020$

Traducción : Susana Martha Gurovich [susanamarthag@gmail.com]

\section{Introducción}

1 Al situarnos en el marco del programa de investigación empírica "Curso de acción" (en adelante CdA) (Theureau, 2004, 2006) o de "antropología cultural enactiva" (Theureau, 2015), estudiamos los procesos de aprendizaje-desarrollo que se ponen en marcha en diferentes dispositivos y contextos de formación profesional (salud, educación, deporte). Nos interesamos especialmente en la modalidad llamada de aloconfrontación [1], que consiste en confrontar a quienes están en formación con filmaciones de pares 
en situación de trabajo, de simulación o de comentarios sobre la actividad filmada. Esos dispositivos de video-formación contribuyen a estimular, anticipar y acompañar aprendizajes profesionales. Dichos contextos demandan y articulan procesos miméticos, reflexivos, proyectivos y lúdicos, basados en una actividad de comparación entre lo que los actores en formación perciben de una situación filmada-comentada o filmada-simulada y lo que hacen en la realidad de su trabajo en situaciones similares, o lo que harían en el lugar de los protagonistas filmados. A partir de trabajos realizados inicialmente en dispositivos de video-formación de los docentes (Gaudin, Flandin, Moussay, \& Chaliès, 2018 ; Leblanc, 2018 ; Leblanc, Ria, Dieumegard, Serres, \& Durand, 2008) y utilizando la plataforma Néopass@ction (Ria \& Leblanc, 2011), señalamos que la "eficacia de un dispositivo reside en la forma de mediación que éste establece en la relación que se entabla entre los docentes en formación con su trabajo, es decir, la actividad cognitiva que ese dispositivo tiende a generar en ellos, en situación de videoformación y las transformaciones reales o potenciales de su actividad de enseñanza" (Flandin, Leblanc, \& Muller, 2015, p. 180, traducción libre). La confrontación videoscópica de un par o pares con el trabajo contribuye a "poner en relación" la actividad visualizada con la actividad/experiencia del participante en la formación. En situación de formación, esta comparación se mantiene casi siempre como una actividad implícita, poco explorada y que permanece silenciosa. Los investigadores, por su parte, tienen dificultades para documentar de manera empírica un proceso complejo en el que entran en relación experiencias vividas por los actores.

2 Sin embargo, muchas investigaciones francófonas sobre la video-formación en educación (Flandin, Leblanc, \& Muller, 2015), y trabajos realizados en el campo de la salud (Bouchot \& Leblanc, 2019) y del deporte (Secheppet, 2020), ponen de manifiesto un proceso fenomenológico mimético muy presente y abundantemente documentado. Ahora bien, esta facultad mimética que contribuye a la emergencia del mundo percibido, en el origen de todo conocimiento, es sin embargo poco reconocida, tanto en el mundo de la educación como en el de la formación, y poco explotada científicamente pues la concepción filosófica dominante de las modalidades del conocimiento humano "subestima el acceso no reflexivo al mundo que la ejemplificación mimética hace posible" (Schaeffer, 1999, p. 57, traducción libre). El hecho de que esta dimensión antropológica fundamental de la actividad humana no sea tenida en cuenta puede explicarse por muchas razones tales como : la adhesión a una visión racionalista de la construcción de los conocimientos basada en la oposición verdadero-falso, la invisibilidad de los procesos de simulación a los que están sometidas las personas, una concepción seria del conocimiento incompatible con el juego y el placer, o incluso una visión unificada de la identidad personal que descarta la pluralidad de nuestros modos de existencia.

3 Con esta contribución, a partir de datos empíricos procedentes de varios contextos de formación profesional, deseamos dar cuenta de las diferentes maneras de aprehender la acción mimética como "el hecho de imitar", de "entrar en emulación", de "hacer lo mismo" o incluso de "apropiarse" (...) el hecho de "expresar" algo, de "llevar algo a ser representado" o aún de "anticipar" algo" (Wulf, 2007, p. 28, traducción libre). En un primer momento, presentaremos la compatibilidad teórica del concepto de mímesis con las hipótesis de la enacción y de la experiencia que organizan el programa de investigación CdA (Ver San Martin \& Poizat, en este número). La hipótesis de la enacción trata de las interacciones asimétricas que un actor mantiene con su entorno, 
del que eminentemente forman parte los otros actores. La actividad [2] es pues considerada al mismo tiempo como individual y social (Theureau, 2006). En un segundo momento, nos preguntaremos cuál es, en situación de formación profesional, la naturaleza de esta actividad individual-social durante una confrontación con la actividad de otros actores en dispositivos de video-formación y/o de observación de pares o de expertos.

4 Al posicionarnos en un situacionismo metodológico (Theureau, 2006) que descarta una focalización sobre las características individuales de los actores (individualismo metodológico) o sobre las características de los colectivos (colectivismo metodológico), contribuiremos al enriquecimiento del conocimiento de esta actividad individual-social especificando cómo el actor en situación de formación tiene en cuenta la actividad del otro o de los otros en relación con su propia actividad. Desarrollaremos hipótesis de conocimiento relativas a los procesos miméticos y ficcionales que se pondrían en marcha en esas situaciones de formación. Actualizaremos las condiciones que deben darse para posibilitar que se exprese la conciencia prerreflexiva del actor (Theureau, 2011) cuando es confrontado con la actividad de sus pares (aloconfrontación) en situaciones de video-formación y/o de observación de simulación. Asimismo, daremos cuenta, desde un punto de vista teórico-metodológico, del modo en que rastreamos las "transformaciones silenciosas" que tienen lugar al poner en relación la actividad visualizada-observada de par(es) con la actividad del observador-actor a lo largo de períodos más o menos largos (de algunas horas a varios meses). Finalmente, examinaremos los aportes y los límites de esta contribución tanto desde el punto de vista teórico como el de diseño de espacios de formación inmersivos.

\section{Marco conceptual para aprehender el aprendizaje- desarrollo}

5 Para tratar de comprender el aprendizaje-desarrollo en contextos en los que éste es el objetivo al que se apunta, es necesario proponer una teoría de la formación que permita dar cuenta de las condiciones para acceder a las transformaciones inherentes al proceso de aprendizaje-desarrollo. Esta teoría de la formación debe asimismo permitir explicitar la manera en que se cruzan los procesos de construcción de la actividad y de los sujetos (Barbier, 2009). Para explicar ese proceso de aprendizaje-desarrollo que no reducimos ni a la "propiedad" de un sujeto ni a una "determinación" social, tratamos de aprehender, apoyándonos en el marco teórico del programa de investigación CdA, las "propiedades relacionales" del tríptico actor-entorno-otro a través del análisis de las transformaciones de la actividad. El análisis de los "cursos de acción" y del "curso de vida relativo a una práctica" nos permite aprehender la dinámica de la actividad "rastreando" las "nuevas posibilidades o "posibles"" que se abren en situaciones de aloconfrontación intermediadas por el video. Entre esos posibles, nos centramos en aquellos que se actualizan en la relación entre la actividad real del otro y la actividad imaginaria del observador o de la observadora, transformando de hecho los saberes a través de procesos de fortalecimiento, invalidación o creación de tipos [3]. Para analizar las transformaciones de la actividad en situaciones de formación que apuntan a provocar un aprendizaje-desarrollo profesional, desarrollamos dos hipótesis relativas a los procesos de autopoiesis y de tipicalización, por un lado, y a los procesos de mímesis y de ficción, por otro. 


\subsection{Autopoiesis y tipicalización}

Concebimos la construcción de los conocimientos como resultante de un proceso autopoiético (Maturana \& Varela, 1994) y de tipicalización (Rosch, 1973; Theureau, 2004). La teoría de la autopoiesis define el aprendizaje-adaptación como una "deriva estructural continua" (Maturana \& Varela, 1994) en la que el "acoplamiento estructural" (ej. la historia continua de las relaciones que un organismo vivo mantiene con su entorno) es regulado por un mecanismo autorreferencial. Esta autoreferencialidad funciona como un proceso de "reconocimiento" en función de la identidad del sistema, lo que le confiere su inteligencia. "Nuestra relación con el mundo se produce como en un espejo, que no nos dice ni lo que el mundo es ni lo que no es. Ella sólo deja ver que nos es posible tener nuestro modo de ser y nuestro modo de actuar, y que solo así nuestra experiencia es viable" (Varela, 1989, p. 31, traducción libre). La experiencia del aprendizaje-desarrollo, concebida como la transformación permanente de la actividad producida por su propia dinámica y por su adaptación al entorno, es guiada por ese proceso de auto-referencialidad que se organiza alrededor de un proceso autónomo de creación de sentido. El acoplamiento actor-entorno hace que emerja la situación en la cual el actor construye el sentido al movilizar sus referencias localizadas, en un modo compatible con el mantenimiento del equilibrio de las estructuras internas del acoplamiento. Asimismo, ese acoplamiento delimita de manera autónoma el campo de interacciones posibles con el entorno, en la medida en que selecciona lo que este último le ofrece en función de su pertinencia significativa y en relación con su cierre operativo. Los saberes construidos a través de esta dinámica de interacciones asimétricas propias del acoplamiento actor-entorno resultan de la identificación de un conjunto de semejanzas/diferencias entre diversas experiencias tipicalizadas.

7 La situación de aloconfrontación en video-formación tiene la particularidad de crear un acoplamiento en el que el actor interactúa con la situación parcialmente develada de un par. La actividad de comprensión y de interpretación de la actividad de ese otro potencia el proceso de reconocimiento : el/la observador/a experimenta familiaridad/ extrañeza respecto de la situación del otro en relación con sus propias experiencias tipicalizadas, accediendo al reconocimiento de una similitud entre acciones realizadas con anterioridad y las acciones observadas. Las declaraciones de una docente-pasante confrontada con los comentarios de una colega en un video, ilustran ese proceso de auto-referencialidad y reconocimiento: "Es una situación que me habla, en realidad, eso puede pasarme, ehhh, bueno, según el contexto, la clase, también mi estado de cansancio o mi humor, de ponerme en una situación como esa en la que no voy a hablar más". Ese proceso de tipicalización explica, en parte, las posibilidades de transferencia de los saberes propios del actor de una situación a la otra.

8 Lo que define la pertenencia a una misma categoría de situaciones, es un gradiente de tipicidad en relación con uno o algunos de los ejemplares prototípicos (Rosch, 1973), o un aire familiar entre los elementos de la categoría (Kleiber, 1991). Así, en el ejemplo dado, la docente establece ese acercamiento entre las dos experiencias de clase mientras que las vivencias de ambas docentes son diferentes: "En cambio, lo que hago distinto, en realidad, es que, bueno, eventualmente, los brazos cruzados, los alumnos pueden ver un :" Uf, estoy harta", pero permanecer completamente inmóvil y con la mirada fija, bueno, pienso que eso no los intimida en realidad, y sienten que una se aleja, se ausenta. Entonces, lo que 
yo hago, es que puedo estar en esa posición y desplazarme o recorrer la clase con la mirada y mirar fijo a un alumno...". Un poco más tarde, ella se proyectará circulando por su clase para no dar una imagen negativa a los alumnos. Aprender en una situación de aloconfrontación consiste entonces, por una parte, en responder a las perturbaciones producidas por la observación del otro (estabilizando interpretaciones y tipos o creando nuevos tipos), y por otra parte, en proyectar transformaciones consideradas posibles y realizables, de sus modos de percibir y de actuar en la situación meta. Los saberes construidos durante esas interacciones llevan la impronta de los diferentes acoplamientos actor-entorno puestos en paralelo (la situación observada, la situación recordada, la situación futura imaginada). A esta primera hipótesis de autopoiesis y de tipicalización, le agregamos una segunda hipótesis que remite a las nociones de mímesis y ficción.

\subsection{Mímesis y ficción}

9 Basándonos en los trabajos de antropología histórica y cultural de Wulf (2007) relativos a la mímesis social, consideramos que aprendemos un acto social "por mímesis, en una relación con otros individuos que vemos actuar y con los que estamos conectados por el entorno social. Vivimos la manera en que escenifican y representan sus actos, participamos en sus acciones, hacemos la experiencia de los objetivos que persiguen, del sentido que dan a lo que hacen, y de la relación de sus comportamientos con el contexto" (Wulf, 2007, p. 9, traducción libre).

Dado que las situaciones de formación estudiadas están sistemáticamente marcadas por la referencia a un tercero (confrontación con videos en directo o en diferido del trabajo del otro), esos procesos miméticos les son sumamente necesarios. La incorporación del mundo social a su propio mundo puede realizarse "ya sea por la participación directa en los actos sociales, ya sea por intermedio de la imaginación" (Ibid., p. 11, traducción libre). Defendemos pues la idea de que el aprendizaje-desarrollo en formación implica una "experiencia mimética y ficcional" (Durand, 2009) que se apoya en la hipótesis general desarrollada por Schaeffer (2002) : "en ciertas situaciones, el imaginario, no sólo no nos impide alcanzar lo real, sino que es una condición indispensable para alcanzarlo" (Schaeffer, 2002, p.1, traducción libre). Las situaciones de formación, especialmente cuando tratan de establecer un vínculo estrecho con el entorno de trabajo, implican necesariamente un componente ficcional activo (Durand, 2008; Pastré, 2005), que puede ser más o menos intenso en función de la naturaleza de las situaciones implementadas : simulación, análisis de prácticas, video-formación, juego de roles, etc. Esas "puestas en situación dinámica" favorecen una inmersión mimética que requiere al mismo tiempo de procesos de identificación, de investigación y de producción de similitudes entre objetos, fenómenos y actividades, por comparación de situaciones vividas pasadas y presentes $\mathrm{y}$, simultáneamente, de procesos de anticipación y de proyección en una situación futura. Esta búsqueda de similitud, de aires familiares, no sirve para realizar una copia exacta de lo real (todo acto social permanece único) sino para tomar una "huella" de las acciones sociales anteriores que permite "crear una relación con otro mundo" (Wulf, 2007, p. 10).

Los "detonantes miméticos", ya sea en forma de "parecidos cuasi-perceptivos" a través de extractos de filmaciones grabadas o una filmación en directo, ya sea en forma de "parecidos verbales" (Schaeffer, 1999) o a través de comentarios de los actores, 
permiten a quienes están en formación actuar de manera imaginaria con dos tipos de actividad : por una parte, el de la realidad de la actividad profesional a través de la confrontación a experiencias significativas que hacen eco a su propia vivencia y preocupaciones; y por otra parte, el de un entorno de formación que favorezca desplazamientos profesionales ficticios y reflexivos que puedan desembocar en posibles de acción considerados transferibles en lo real.

De este modo, el universo creado por la confrontación a extractos de filmaciones grabadas o en directo no se conforma con solicitar un proceso de imitación y de "fingimiento", sino que constituye realmente un vector de aprendizaje-desarrollo al ofrecer la posibilidad de construir un cierto número de saberes. En efecto, los procesos miméticos "no producen simples copias de mundos simbólicos anteriores", sino que dan origen a un "trabajo de apropiación y de incorporación" otorgando a esas relaciones miméticas "un aspecto creativo" que modifica "sin cesar los mundos originales de referencia" (Wulf, 2007, p. 64, traducción libre). Esos saberes miméticos construidos son ante todo "de naturaleza corporal y estrechamente ligados a procesos sensibles" (Ibid., p. 11, traducción libre). Los participantes en la formación transponen lo que perciben, y sienten la manera de actuar del otro en un escenario social particular, "por los sentidos y la imaginación en imágenes internas, en mundos de sonido, de tacto, de olfato y de gusto que incorporan a su propio mundo" (Ibid., p. 11, traducción libre).

13 Formulamos la hipótesis que tener en cuenta esos procesos miméticos permite asignar un rol central a la performatividad corporal que las teorías de la acción focalizadas solamente en los aspectos cognitivos no tienen en cuenta. Los detonantes miméticos constituidos por la actividad del otro (manifiesta o implícita) en situación profesional (real o simulada) favorecen el compromiso de los participantes en formación con la actitud de "hacer como si", lo que les permite deslizarse hacia un universo ficcional. Esas inmersiones miméticas provocarían una "remodelación de la experiencia" por el hecho de poner en consonancia una doble dinámica [4] que une experiencias pasadas vividas en situación de trabajo con experiencias vividas durante la confrontación con la actividad del otro (Bouchot \& Leblanc, 2019 ; Leblanc, 2014 ; Ria \& Leblanc, 2011). Esto plantea, de aquí en más, la cuestión de los métodos que permiten aprehender y analizar esas oportunidades de desarrollo de la actividad, que surgen a través de la articulación dinámica, invisible y silenciosa de esos diversos registros de experiencia.

\section{Documentar dichos procesos miméticos y ficcionales en tres contextos de formación profesional}

14 Las tres situaciones de video-formación presentadas en este artículo tienen naturalezas diferentes, ya sea por el punto de vista de la selección y del cúmulo de los métodos, ya sea por las técnicas de entrevista utilizadas en relación con las hipótesis de conocimiento relativas a los procesos miméticos y ficcionales.

\subsection{Autoformación de docentes en un espacio de video-formación}

15 La primera situación de autoformación se desarrolla en un espacio de video-formación sobre la actividad ordinaria de docentes noveles. Se desarrolla en paralelo con la actividad de trabajo real (formación de los docentes). Docentes-pasantes de francés y 
matemáticas realizaron sesiones de trabajo con la plataforma Neopass@ction [5] (Leblanc, 2014 ; 2015 ; Leblanc \& Ria, 2011 ; Leblanc, \& Sève, 2012). Al mismo tiempo que navegaban libremente por la plataforma en presencia del investigador, se las invitaba a producir "verbalizaciones simultáneas e interruptivas" (Theureau, 2004) durante entrevistas filmadas de una hora de duración cada una (Figura 1).

Figura 1 : Verbalizaciones simultáneas e interruptivas

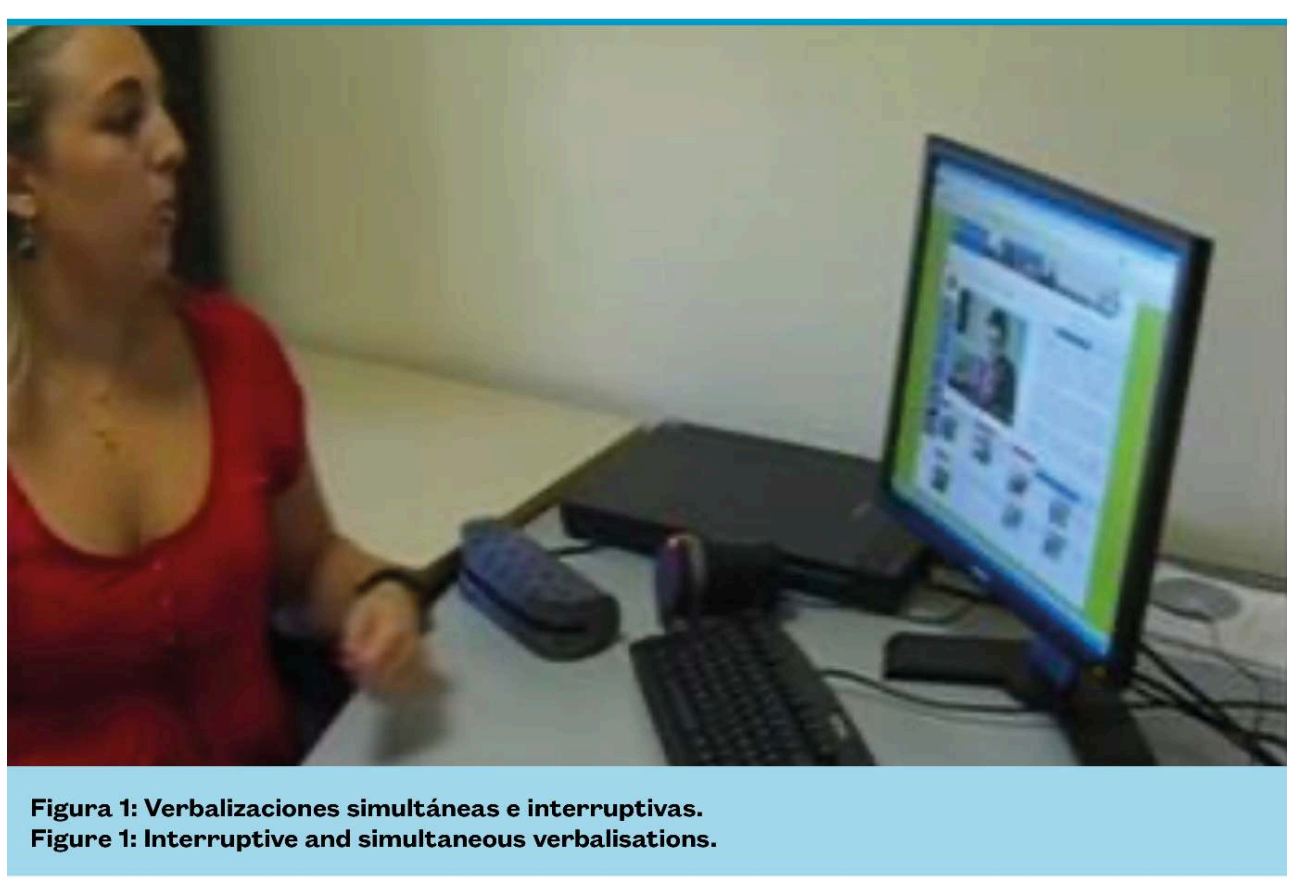

Figura 1 : Verbalizaciones simultáneas e interruptivas

Los datos de verbalización se obtuvieron a través de preguntas y reformulaciones del investigador-interlocutor que invitaba a la docente, mientras navegaba, a explicitar su actividad en la plataforma. Las reformulaciones tenían por objeto facilitar: a) la descripción de su "conciencia prerreflexiva" mientras navegaba, b) la explicitación del punto de vista adoptado sobre la situación (el de la docente, de los alumnos, de un alumno o de ella misma como docente), c) el compromiso y la continuidad en esa situación de formación y d) la formulación de pistas concretas que ella consideraba testear en su clase (auto-prescripciones). Durante la sesión de trabajo siguiente (después de un intervalo de alrededor de un mes), la entrevista comenzaba con la explicitación de lo que efectivamente se había aplicado en clase a partir de las autoprescripciones construidas en la sesión precedente. En el caso de que no hubiera tenido lugar esa aplicación, se le pedía que explicara las razones por las que no lo había hecho. Estos diferentes métodos se articularon para captar y comprender las transformaciones emprendidas o abandonadas por la docente. 


\subsection{Observación de matronas en formación durante las sesiones de simulación en alta-fidelidad retransmitidas en directo en pantalla grande}

17 La segunda situación es una situación de observación de pares en pantalla grande durante sesiones de simulación en alta-fidelidad (SHF, Simulation Haute-fidélité) que se hicieron en directo sobre casos extraordinarios (formación de matronas). El estudio pone el foco en la actividad de observación de cinco estudiantes de cuarto año, inscriptas en un módulo optativo de simulación en alta-fidelidad (SHF) llamado "Urgencias obstétrico-pediátricas" (Bouchot \& Leblanc, 2019). Se hicieron cinco sesiones distribuidas en el primer semestre de 2016. Cada estudiante se ofrece como voluntaria para actuar en dos situaciones simuladas, una vez como matrona y una vez como asistente. En las otras tres sesiones, son observadoras. El método consistió en la realización de entrevistas de auto-confrontación teniendo en cuenta las múltiples trazas de la actividad : la grabación de la pantalla de proyección de cuatro entradas que reproduce en directo la simulación realizada por los pares, la grabación audio-video de varias observadoras (filmadas de frente), las trazas de la actividad de escritura que acompaña a la observación (Figuras 2 y 3).

Cada entrevista requirió la expresión de la conciencia prerreflexiva de las observadoras gracias a una puesta en situación dinámica, posibilitada por una parte, por las diversas trazas de su propia actividad y por otra parte, por la formulación de las preguntas del investigador (Theureau, 2011). Las condiciones materiales y dialógicas seleccionadas tenían por objetivo des-situar a la observadora de la situación presente, re-situarla en la situación estudiada y mantenerla ahí para acceder a las significaciones construidas paso a paso. El método no buscaba obtener nuevas tomas de conciencia, al contrario, buscaba evitarlas. La conducción de las entrevistas consistía, en la medida de lo posible, en proscribir las preguntas que pudieran sacar a las observadoras de la vivencia o revivencia de la actividad con la que estaban siendo confrontadas (¿Por qué ?), en utilizar preguntas o reformulaciones vacías de contenido (¿Y ahí ?) o incluso en resituarlas aquí y ahora utilizando el presente (Acá, usted escribe...). En total, se realizaron 13 entrevistas de auto-confrontación. 
Figura 2 : Datos que documentan la actividad explícita de las observadoras.

De izquierda a derecha : Situación de simulación observada/ Grabación de audio- video de las observadoras / Trazas de la actividad de escritura

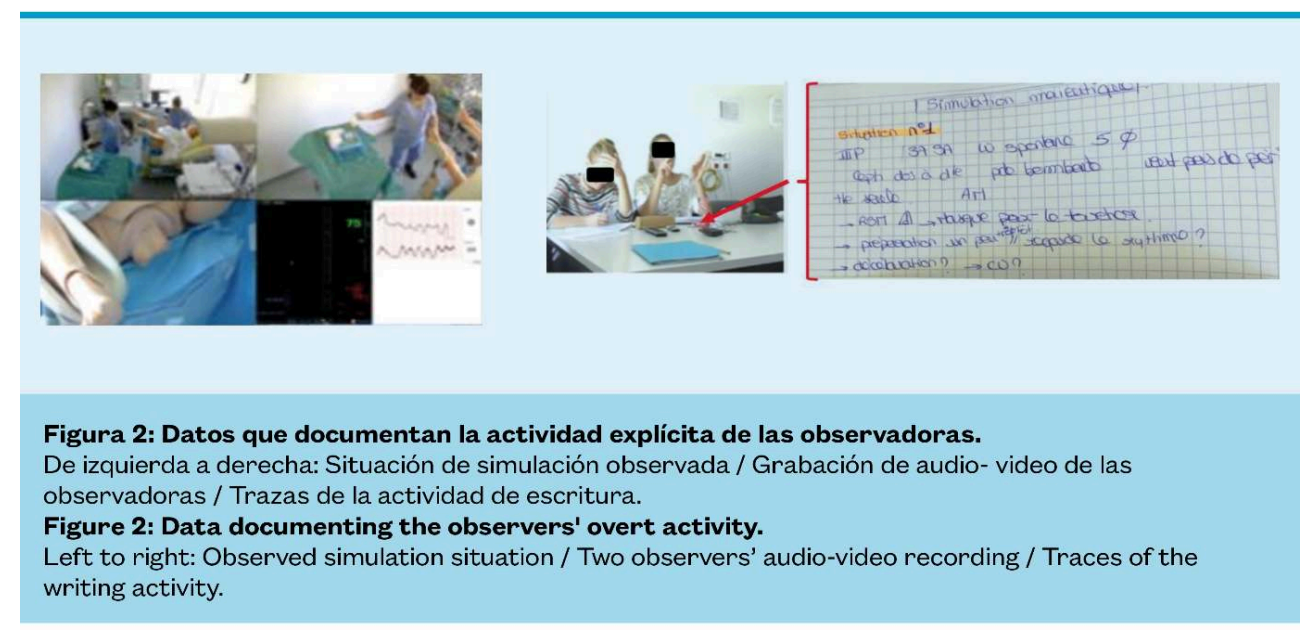

Figura 2 : Datos que documentan la actividad explícita de las observadoras.

De izquierda a derecha : Situación de simulación observada/ Grabación de audio- video de las observadoras / Trazas de la actividad de escritura

Figura 3 : Entrevista de auto-confrontación simple de una observadora con las trzas de su actividad

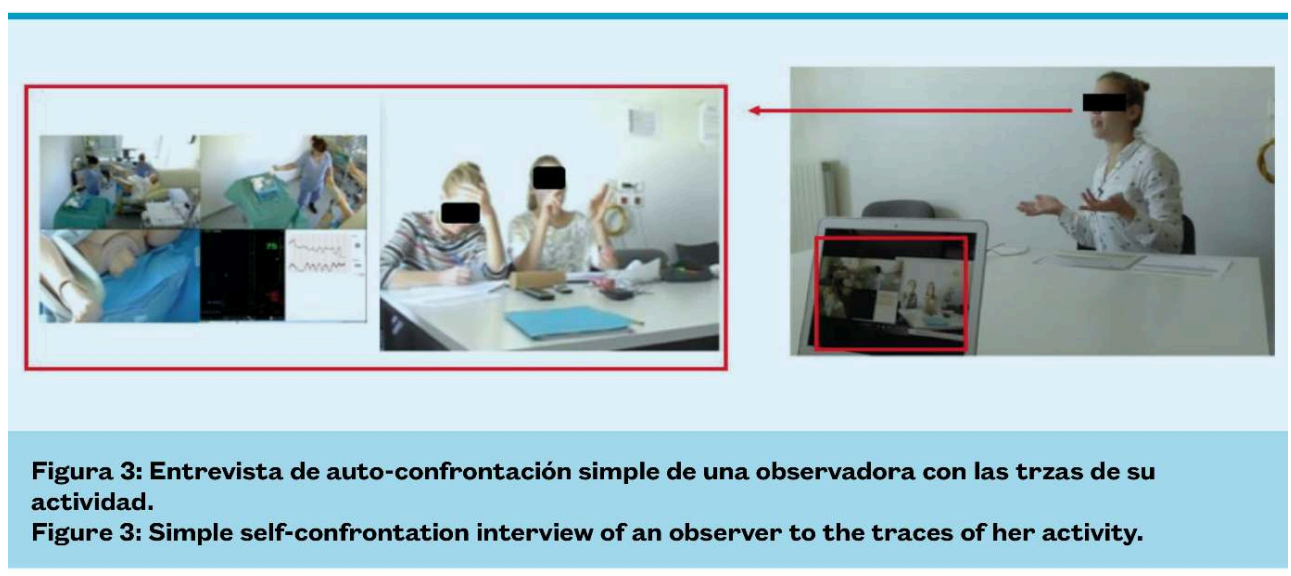

Figura 3 : Entrevista de auto-confrontación simple de una observadora con las trzas de su actividad

\subsection{Auto-formación en un espacio de video-formación y simulación para la conducción de carruajes}

El tercer estudio trata de una situación de auto-formación de treinta minutos de duración, vivida por una pasante en un espacio de video-formación para la conducción de carruajes [6]. Este dispositivo de video-formación, nuevo en el ámbito de la formación [7], fue presentado a las pasantes al comienzo de la formación para que tuvieran la posibilidad de utilizarlo autónomamente conectándose con su nombre de usuario. Dos meses después del inicio de la formación, en el momento en el que tiene lugar la situación estudiada, las pasantes no habían utilizado aún esa herramienta con su formador. Además, la investigadora, en inmersión etnográfica sobre la totalidad de la formación, fue identificada por las pasantes como una pasante particular que hacía 
una investigación sobre su actividad. Nadège, la pasante implicada en este estudio, ya había tenido una entrevista de auto-confrontación en una situación de conducción en el transcurso del primer mes de formación. También participó en filmaciones etnográficas durante las cuales la investigadora grabó su actividad de conducción. Por el contrario, la pasante no había explorado la plataforma de video-formación. La participación en esa situación de auto-formación resultó de una negociación entre la investigadora y la pasante. Esta negociación concluyó en el siguiente acuerdo: la investigadora se comprometía a acompañar a la pasante en el descubrimiento de la plataforma de videoformación, delegando en ella la navegación, y, a cambio, la pasante aceptaba consagrar una parte de su tiempo libre a la investigadora para que ésta pudiera reunir datos para la investigación sobre su actividad de navegación/visualización en el dispositivo de auto-formación.

Los videos de esta plataforma tienen la particularidad de mostrar la actividad ordinaria de cocheros experimentados. Pero al momento de descubrirlos, la pasante no conoce la pericia de esos cocheros de carruajes.

Durante la situación de auto-formación seleccionada, la entrevista negociada con la pasante propone articular el "decir a la investigadora lo que estoy haciendo" en base a "pensar en voz alta", con reformulaciones de parte de la investigadora en forma de verbalizaciones simultáneas interruptivas (como para el estudio 1 de la situación de la docente). Esta articulación tiene en cuenta la supervisión que hay que ejercer sobre el mantenimiento de la actividad de navegación/visualización con el fin de documentar bien de cerca la conciencia prerreflexiva de la pasante. En ese sentido, la investigadora también se ocupó de intervenir en los momentos que ella consideraba oportunos para garantizar la dinámica de la actividad en curso.

Esta situación de navegación/visualización mediada por la investigadora fue el punto de partida de una transformación significativa para la pasante, por la emergencia de una novedad en su "mundo, cuerpo y cultura" propios: "la historia del peso" (ver 5.2.2). Dicha transformación, que aparece en esta situación de visualización, se prolonga en los días siguientes y acompaña a la pasante hasta el final de su formación. La investigadora reconstruyó esa transformación en esta pasante reuniendo datos etnográficos varios, las verbalizaciones en entrevistas acerca de su actividad en situación de conducción, de su actividad de visualización y de simulación en la manipulación de las riendas, así como una entrevista en la que invitaba a la pasante a mirar retrospectivamente su formación.

La línea de tiempo (Figura 4) permite ver el conjunto de datos construidos específicamente con esta pasante. La columna verde indica la situación presentada en este artículo. 
Figura 4 : Línea de tiempo de los datos construidos con la pasante Nadege

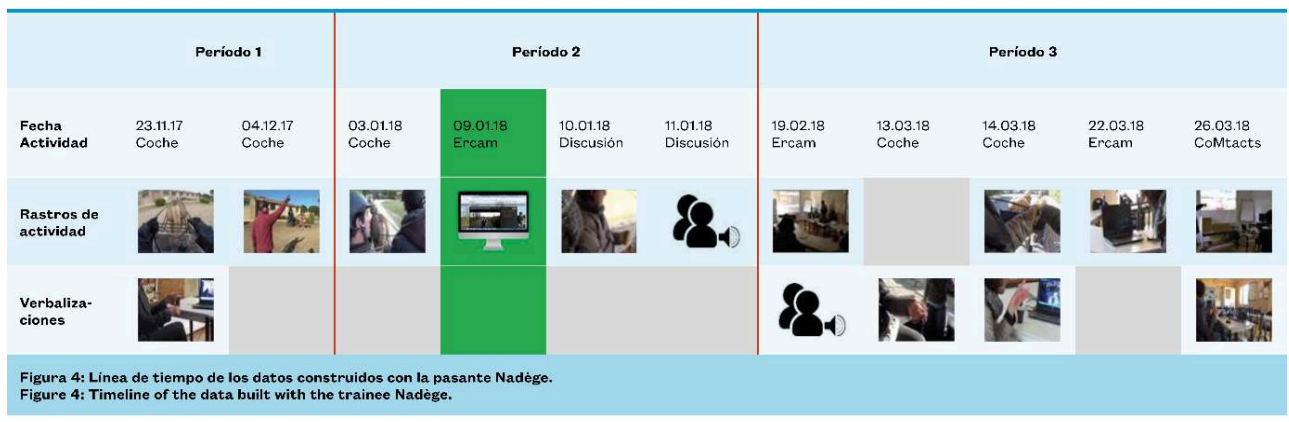

Figura 4 : Línea de tiempo de los datos construidos con la pasante Nadege

\section{Traducción teórica de los procesos miméticos}

Para comprender más en profundidad los procesos miméticos implementados en esas diferentes situaciones de formación, proponemos una contribución teórica para el programa de investigación $\mathrm{CdA}$, con nuevas pistas de análisis para captar mejor las dimensiones implícitas de la actividad corporal y sensible, muy presentes en esa relación mimética con el mundo del otro, y comprender mejor las condiciones de performatividad [8] de la acción.

\subsection{La hexatomia de la unidad de la experiencia}

Un curso de experiencia está compuesto por una concatenación de unidades de actividad significativas para el actor, o de unidades de curso de experiencia. Cada una de esas unidades surge de un signo hexádico que une seis componentes (Figura 5) y que da cuenta de los procesos esenciales en la construcción de la experiencia humana [ $\left.{ }^{\circ}\right]$. Los tres primeros componentes constituyen la estructura de expectativa del actor, que delimita el campo de los posibles de la actividad en el instante $t$ (Compromiso en la situación; Actualidad potencial o Estructura de anticipación; Referencial). Los dos componentes que siguen constituyen la actualidad del actor en el instante $t$ (Representamen ; Unidad del curso de experiencia). Finalmente, el último componente traduce la construcción de un saber inherente a la unidad de curso de experiencia en el instante $t$ (Interpretante). Lo que es más actual para el actor corresponde a la unidad de curso de experiencia (o unidad significativa) U en relación con un Representamen R. Esta unidad describe la experiencia del actor en el instante $t$ relacionado con su actividad, que puede ser mostrada - incluso mimada - y puesta en palabras. Casi siempre, traduce una acción (Práctica o de comunicación) o un sentimiento. 


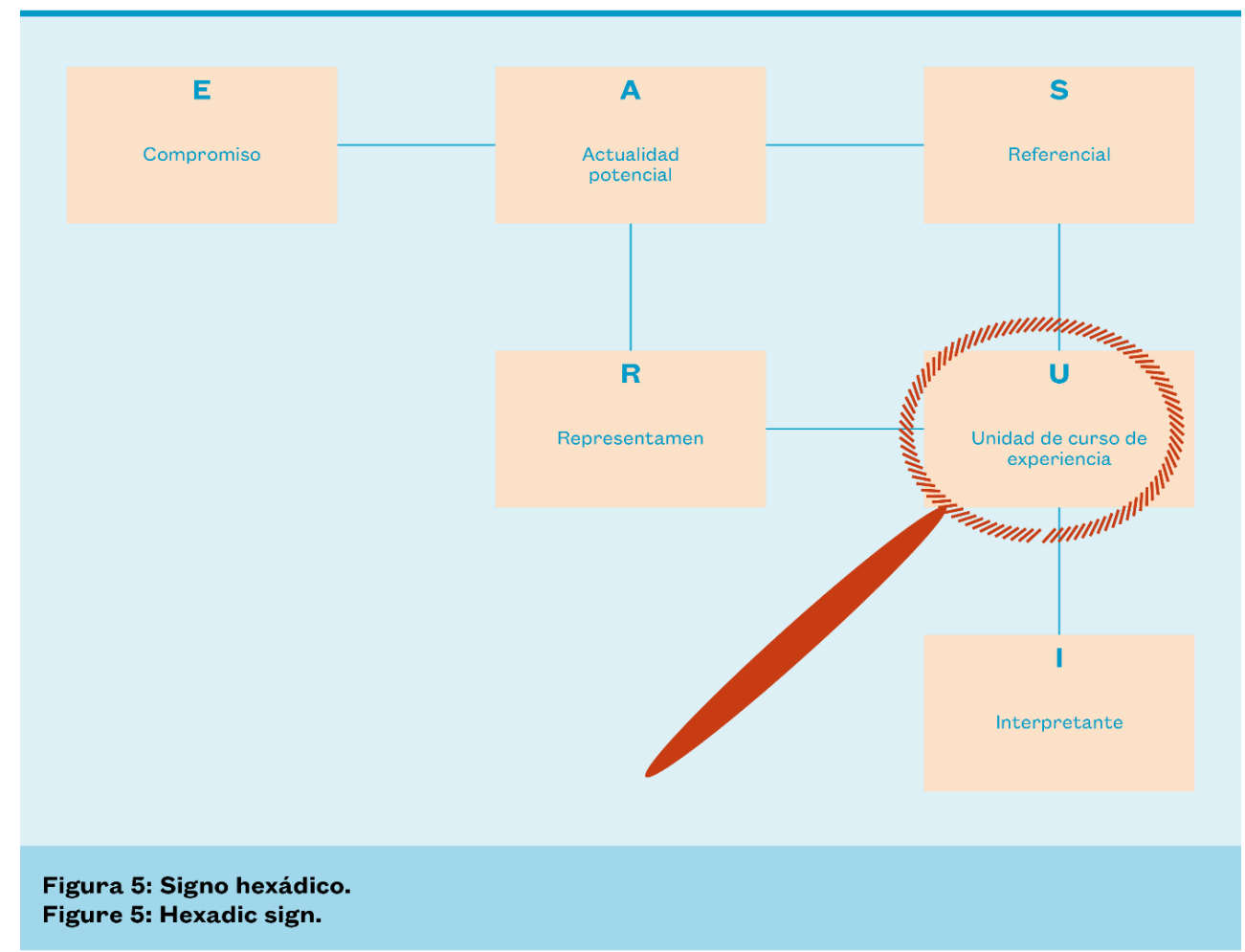

Figura 5 : Signo hexádico

Para explicar mejor los procesos miméticos (inmersión, imitación, emulación, "hacer lo mismo", representación, anticipación) y la performatividad corporal evocados anteriormente, exploramos y aprovechamos el potencial de la hexatomia de la unidad del curso de experiencia U que ofrece posibilidades nuevas de descripción de la actividad con mucho detalle [10], a partir de sub-componentes abstractos propuestos por Theureau $(2006,2009)$. La hexatomia de la U (Figura 6) se organiza sobre la base de las mismas relaciones reales ${ }^{[11}$ y de pensamiento [12] que el signo hexádico. Eso significa que si el investigador ve aparecer una acción o imaginación [U.2.2] en la experiencia del actor, esta última es por hipótesis, consecutiva a un impulso [U.1.1] y a la emergencia de un sentimiento [U.2.1]. 
Figura 6 : Hexatomia de la unidad de la experiencia

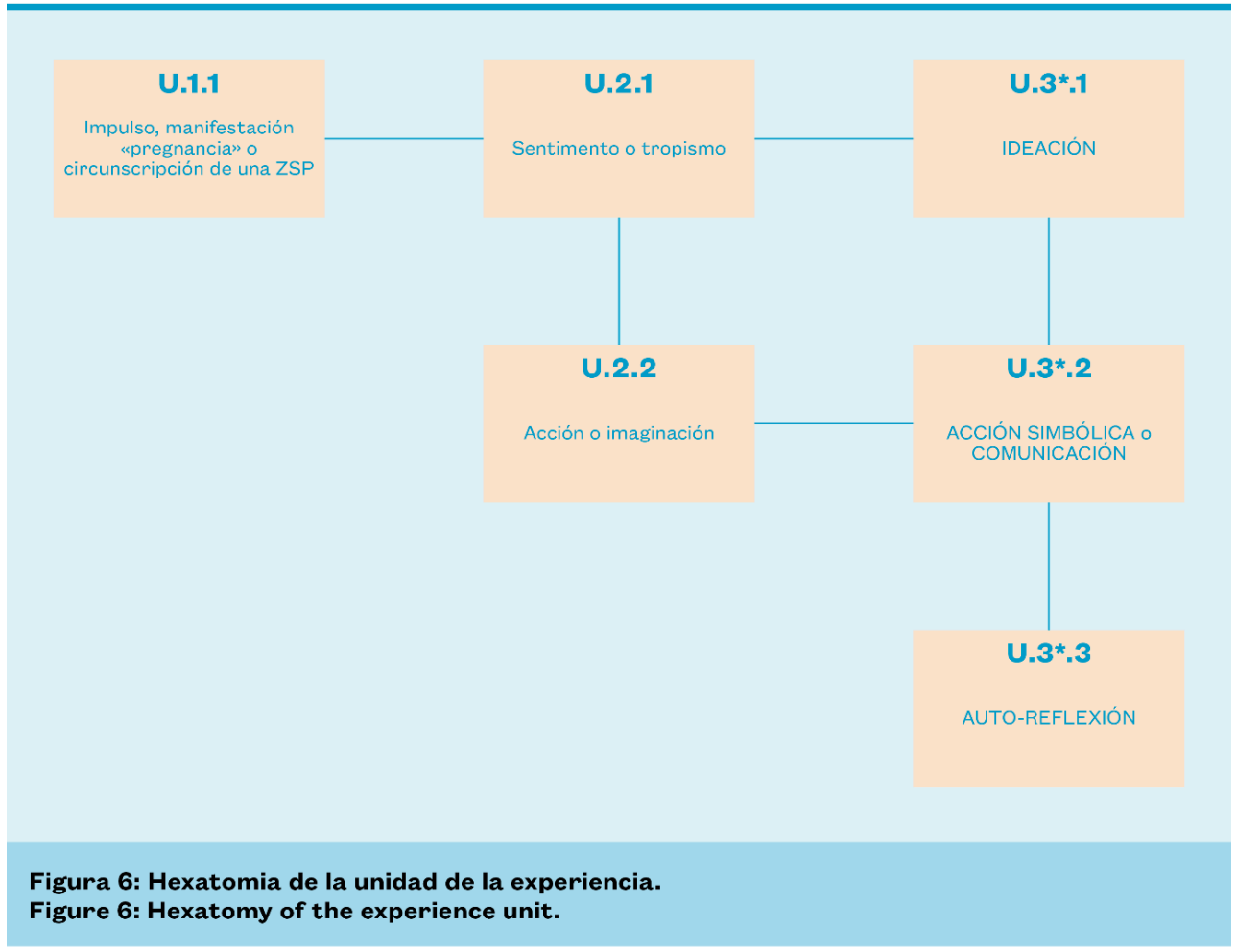

Figura 6 : Hexatomia de la unidad de la experiencia

27 Este aspecto nos parece importante pues las U que dependen de un carácter degradado, es decir que terminan en la declinación de la hexatomia con un .1, están acompañadas por un porcentaje de indeterminación o de indefinición, a causa de su carácter primero (ej. de su carácter de Primeridad o Posible). En esto, son difíciles de detectar al mismo tiempo por el observador externo y por el actor. Para poder documentarlas, el actor debe reconectar con su vivencia y explorar los momentos borrosos, fugaces, difíciles de poner en palabras.

El marco metodológico del programa CdA permite completar la dinámica de la actividad documentando-describiendo la conciencia prerreflexiva asociada a la situación (principalmente a partir de los métodos de verbalización simultánea y de autoconfrontación). Permite asimismo captar detalles sensoriales y emocionales de la acción, especialmente a partir de una puesta en situación a través de las trazas que quedaron en el cuerpo de los actores. Toda la dificultad metodológica reside en la articulación de esta doble exploración : la de la dinámica temporal y cultural de la actividad (sobre intervalos más o menos grandes) y al mismo tiempo, la de la experiencia sensible en profundidad del aquí y ahora. Para avanzar sobre esta cuestión difícil, algunos investigadores (ej. Azéma, 2015; Azéma, Secheppet, \& Mottaz, 2020 ; Cahour, 2006) realizaron comparaciones teóricas y combinaciones metodológicas provenientes de la antropología cognitiva, de la etnografía y de la psico-fenomenología. Nosotros en cambio, para sostener nuestra hipótesis sobre la función mimética, mostramos cómo tratar datos refinando las categorías de análisis que permiten formalizar las transformaciones en curso (impulso, sentimiento, imaginación...) más que la manera de construirlas sobre el terreno y en colaboración con los actores. 


\subsection{Análisis de la experiencia mimética a partir de la hexatomia de la U}

Para ilustrar el tipo de deconstrucción-reconstrucción de la experiencia mimética a partir de la hexatomia de la U y precisar las definiciones de las sub-categorías, nos apoyamos en el estudio de caso 1 realizado con una docente-pasante que navegó libremente por la plataforma Neopass@ction (una vez por mes durante 4 meses) en presencia del investigador (Leblanc, 2014). Nathalie (profesora de matemáticas) se encuentra escuchando los comentarios de una docente titular novel de Educación física y deportiva (llamada Aude) que comenta y reacciona al ver un video de otro docente en dificultades (llamado Romain) al comienzo de su curso. Nathalie se sentirá atraída por la historia de los "brazos cruzados" a partir de las palabras de Aude como un eco de su propia práctica (Figura 7). Y decidió seguir esta historia deteniendo el video en la postura del docente Romain que permanece de "brazos cruzados" contra el pizarrón.

Figura 7 : Concatenación de dos signos sobre la historia de los "brazos cruzados"

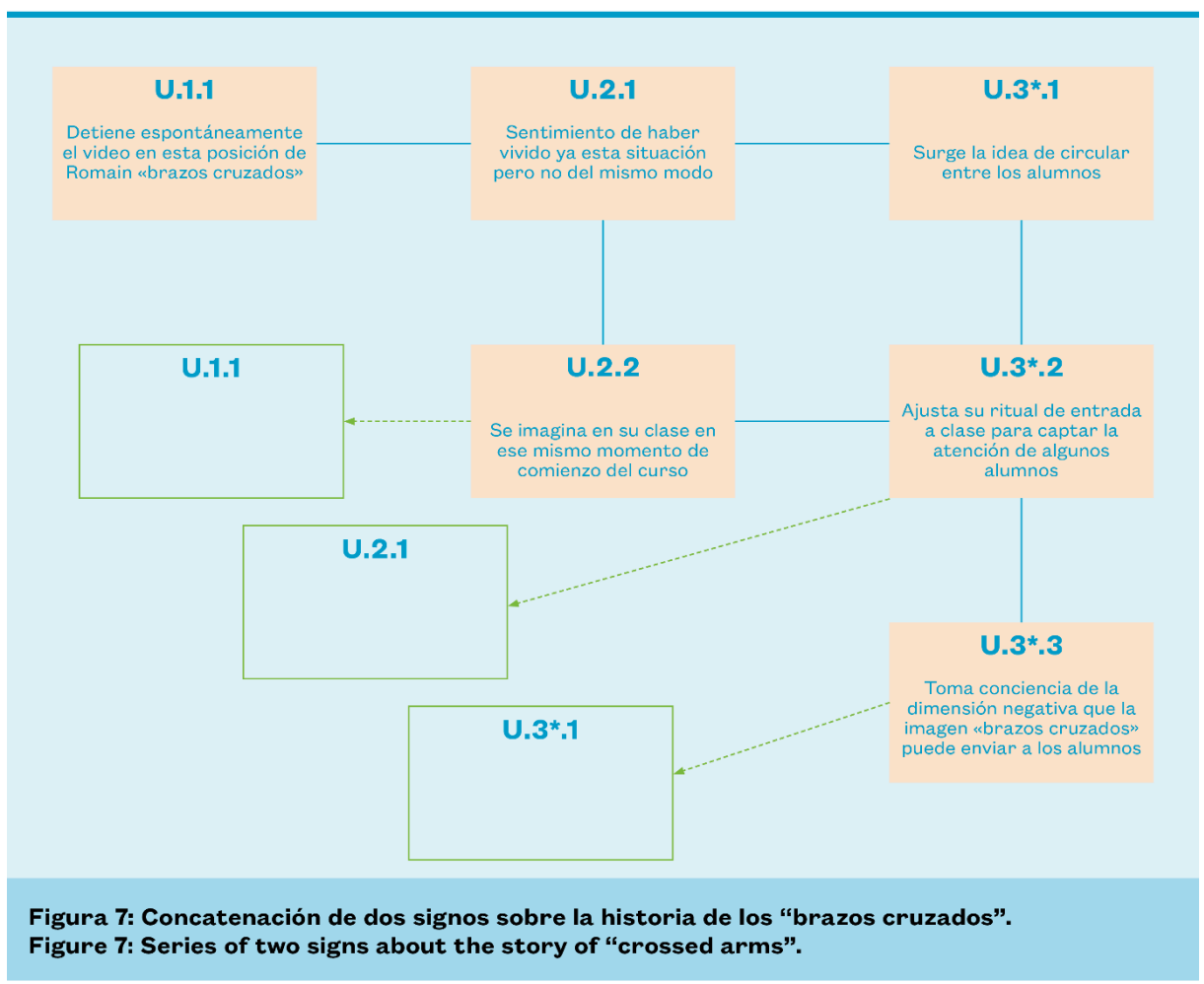

Figura 7 : Concatenación de dos signos sobre la historia de los "brazos cruzados".

Toda aparición de una unidad de curso de experiencia [U] se hace en conexión con una impulsión (indicada [U.1.1]), es decir, una fuerza psíquica, afectiva, nerviosa, sensual, ciega, interior, irracional, irreflexiva, oscura, secreta, repentina, súbita, violenta y espontánea, que se impone a la percepción sin control posible y que empuja a la acción. Durante la escucha del video, Nathalie está muy atenta y cerca de la pantalla [U.1.1]. Al término de la escucha [U.2.2], manifiesta espontáneamente y de inmediato un cierto "acuerdo" con las palabras de Aude relativas al hecho de permanecer con los brazos cruzados, en una misma postura [U.2.1]. Reproduce espontáneamente la postura de los brazos cruzados haciendo la mímica [U.1.1] en función de lo que le hizo "ruido" en las 
palabras de la docente de EPS (Education Physique et Sportive, Educación física y deportiva): "bueno, eventualmente los brazos cruzados, eso puede mostrarles a los alumnos "uf, estoy harta"' (Figura 8). Su movimiento de pensamiento la lleva a posicionarse instantáneamente a propósito de esa postura, que hace eco a su práctica [U.3*.1].

Figura 8 : Hace la mímica de los brazos cruzados

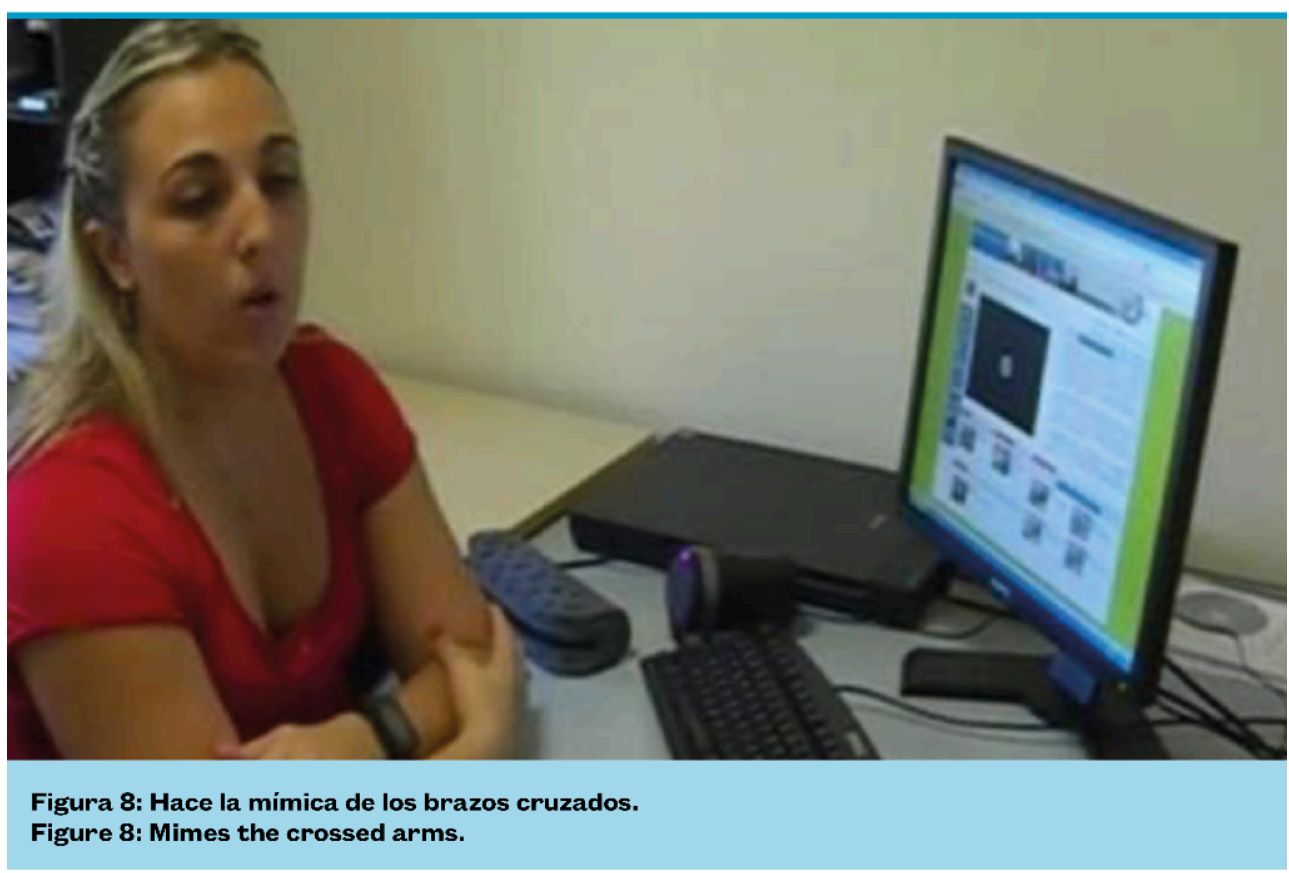

Figura 8 : Hace la mímica de los brazos cruzados

La manifestación de una pregnancia se manifiesta también en el cuerpo que es un "espacio expresivo" "donde, imperceptiblemente, el movimiento se hace gesto, el gesto se hace signo, el signo palabra, sin que se pueda detectar dónde se detiene el movimiento bruto y dónde comienza el signo" (de Saint Aubert, 2010, p. 135, traducción libre). Así, Nathalie mima un barrido con la mirada haciendo movimientos de cabeza y de brazos de derecha a izquierda (Figura 9) diciendo "funciona, pero a condición, como ella dice, de barrer la clase con la mirada" [U.1.1]'. 
Figura 9 : Mima el barrido de la cabeza con los brazos

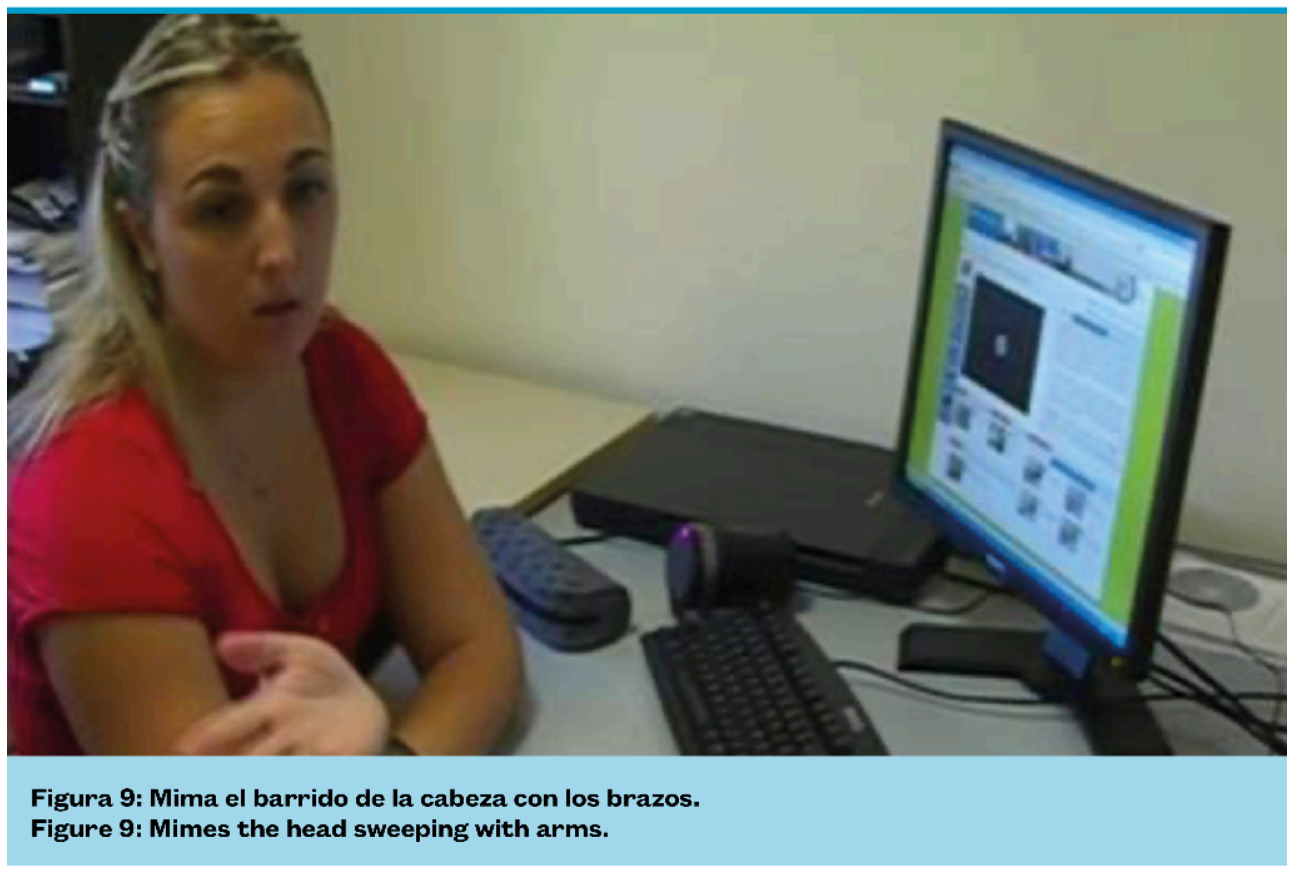

Figura 9 : Mima el barrido de la cabeza con los brazos

Este impulso está acompañado por tropismos [U.2.1], definidos como "movimientos indefinibles, que se deslizan rápidamente hacia los límites de nuestra conciencia" (Sarraute, 1996, p. 1719, citado por Theureau, 2006, p. 336, traducción libre) y que se encuentran en el origen de nuestras acciones y/o emociones. Es por eso que Nathalie experimenta un sentimiento de presencia [U.2.1] en la situación ficticia debido al vínculo de proximidad que ella establece con una vivencia de clase. La concatenación de gestos "icónicos" [13] que miman la postura de brazos cruzados, el barrido con la mirada y los gestos destinados a interpelar a los alumnos (Figura 9) nos permiten decir que entra en el proceso mimético. Esos elementos nos parecen propicios para proseguir esta experiencia mimética a través de una forma de sincronización entre la disposición del actor a actuar en ese mismo momento y el video observado. En este instante, el actor construye a partir de "shocks" diversos (Romain : brazos cruzados mientras permanece quieto), "llamados" constituidos aquí por las propuestas del otro (Aude: brazos cruzados en actividad), pero también "imaginaciones productivas" (Theureau, 2009, p. 104) que le permitirán continuar con el proceso mimético instalándose en la ficción.

El proceso mimético se enriquece gracias a una concientización de los vínculos establecidos entre las experiencias (en formación y/o en el trabajo) que se realiza a través de la imaginación [U.2.2]. La imaginación productiva se logra en base a una recomposición y/o a una articulación de imágenes mentales a partir de objetos ya percibidos y recordados. Las imágenes mentales poseen varios estatus y modos de existencia diferentes según los momentos: antes de la experiencia para anticipar (futuro), durante la misma para percibir (presente) y después como símbolo-recuerdo (pasado). En la prolongación de la acción de mímica de un barrido con la mirada, Nathalie evoca, a partir de "imágenes-recuerdos", una parte de sus propias experiencias que hacen eco a lo expresado por Aude "Entonces, yo me detengo también 
sobre, ehhh, en fin, miro precisamente a los alumnos que no están en su lugar para mî' (Figura $10)$.

Figura 10 : Gesto icónico que apoya la precisión de su mirada

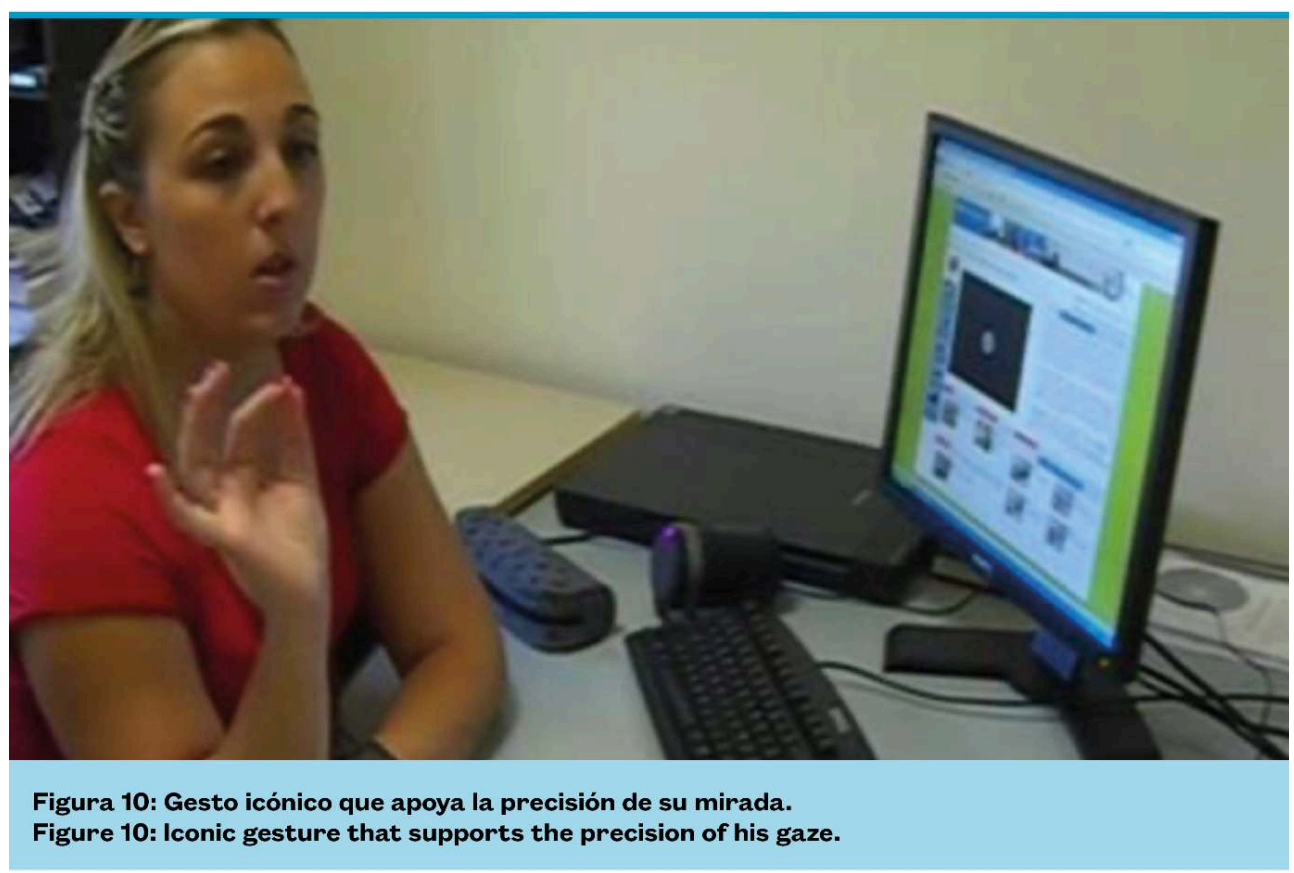

Figura 10 : Gesto icónico que apoya la precisión de su mirada

algunos alumnos: "de hecho, cuando entran a clase están de pie, permanecen de pie, deben sacar todos sus útiles de matemáticas y después, espero el silencio para hacerlos sentar". Al imaginar y reinterpretar ese fragmento de experiencia, ella ve y describe los comportamientos de falta de atención o de distracción de los alumnos y lo que eso la lleva a hacer: "a menudo, hay alumnos que están en la luna, entonces se olvidan de sacar sus cosas. Entonces se los recuerdo. 0 están esos que se sientan antes de que se les diga, entonces, se los recuerdo también".

idea (ideación) [U.3*.1] que corresponde a lo que el espíritu puede concebir como una idea aproximada, compleja, concreta, confusa, distinta, imperfecta, insuficiente, neta, sumaria, superficial, verdadera, débil, difusa, de conjunto. La idea que surge en Nathalie como resultado de esa inmersión ficticia se expresa en un primer momento de manera bastante difusa : "Pero, sin embargo, lo que pienso que voy a, ehhh, que voy a hacer, es efectivamente pasear por la clase". Esta idea de circular entre sus alumnos se construyó a partir de los comentarios de Aude que mostraba en sus palabras la necesidad de estar activa para que los alumnos comprendieran su presencia y sus intenciones: "permanecer completamente inmóvil y con la mirada fija, en realidad, pienso que no los intimida", "después tiene que haber algo que se mueva, ya sea la mirada, ya sea desplazarse". Esta idea se afinará y se fortalecerá al ver a Romain apoyado contra el pizarrón en una postura de brazos cruzados [U.3*.1]'.

La unidad de curso de experiencia puede expresarse por una acción o comunicación simbólica [U. $\left.3^{*} .2\right]\left[{ }^{14}\right]$ mientras sea compartida y en consecuencia interpretable por una 
comunidad cultural. Notemos que puede haber varios perímetros de comunidad cultural. Por ejemplo, un pasante se inscribe a la vez : en la comunidad compartida con los otros pasantes, en la comunidad que comparte con los formadores, y en la que comparte con los tutores de la pasantía. Nathalie toma conciencia de que la manera de llevar a cabo su ritual : "Barro con la mirada, pero efectivamente, ehhh, como están de pie, a veces no los veo a todos", así como la organización espacial de su clase : “yo tengo un escritorio que está completamente, no está en el centro, está a la derecha de la clase, bueno, con un ordenador y es cierto que estoy un poco retirada finalmente con respecto a...", no favorece el control de los alumnos solamente con la mirada. Esas dos tomas de conciencia refuerzan así el interés en explorar y testear los desplazamientos en esta fase particular de preparación de los alumnos para el trabajo, durante la cual ella espera el silencio : "justamente mostrar que, bueno, y más fácilmente en todo caso a los que no están en su lugar, bueno, de hacer, ehhh, que se pongan un poquito en movimiento... para que se pongan más rápidamente en posición de trabajo". Esta visión nueva del ritual de entrada a clase y de hacer que los alumnos se activen se construyó al comparar su propio mundo y el de dos mundos pertenecientes a otros y que entran en discordancia (el video donde Romain está con dificultades, que Nathalie ya había visto/ los comentarios de Aude relativos al video de Romain completados con sus propios modos de hacer en relación a la especificidad de EPS). Esta transformación potencial de su ritual de entrada a clase es reforzada por otra comparación efectuada algunos segundos más tarde, que le permitirá tomar distancia de lo que se juega en ese tipo de situación.

Por último, la unidad de curso de experiencia puede resultar en la producción de un discurso auto reflexivo referido a la esencia de todas las otras sub-categorías y sus transformaciones [U.3*.3] (Theureau, 2009). Los juicios surgidos de esta autoreflexividad se expresan siempre a través de un binomio, por ejemplo entre "el que actúa y lo actuado" (Fichte, 2000, citado por Theureau, 2009). Mientras Nathalie se prepara para ver el video de la entrevista en la que se ve a Romain en posición de espera con los brazos cruzados, se tira hacia atrás en su silla y comenta, mimando la postura de Romain [U.3*.2] : “Ah, bueno, tiene una postura contra el pizarrón, se apoya como si necesitara un, un apoyo, algo así. Y eso, ya me habían hecho la observación el año pasado cuando hice la pasantía, tenía un poco esa actitud...". En este punto, es relacionar (el que actúa) la postura contra el pizarrón de Romain, el recuerdo de la devolución de una formadora durante una observación de clase sobre esa actitud (que no había tenido sentido en ese momento, un año antes) y de la vivencia asociada a aquella "yo no esperaba apoyo" [U. 2. 1], que la lleva a tomar conciencia de que esa actitud puede enviar a los alumnos (lo actuado) una imagen completamente desfasada de las intenciones del docente, imagen que se puede calificar de quasi-transparencia [U. $\left.3^{*} .3\right]$ : "finalmente, es como si él se borrara un poco en eso, de, de apoyarse en el pizarrón". Esta auto-reflexión se elabora primero poniendo en relación su propio mundo y el de los otros (Romain y Aude), y así ella construye en cierto modo la importancia de la presencia física y espacial del docente en la clase y luego por la comparación de una experiencia similar surgida de su "pasado lejano" (el año anterior) con el propio mundo de Romain. La auto-reflexión [U.3*.3] que se desplegó a partir de esta secuencia provocó transformaciones reales en su práctica, inspiradas directamente en lo que ella construyó durante su navegación por la plataforma : "No paso más lista, circulo por la clase hasta que todos hayan sacado sus útiles y luego, los hago sentar y ya está. Utilicé un poco lo que había visto, justamente, no quedarse más delante del 
pizarrón esperando, sino circular para mostrar que estoy esperando que estén, en fin, que vayan rápidamente a sus lugares".

\section{Puesta a prueba de la elaboración teórica en otros dos estudios}

Al movilizar esta herramienta conceptual, proponemos ejemplos que ilustran algunos procesos miméticos en otros dos contextos de formación : por una parte, en formación inicial de la práctica mayéutica por simulación en alta-fidelidad (estudio de caso 2) y, por otra parte, en la formación para la conducción de carruajes (estudio de caso 3). El primer contexto de formación tiene la particularidad de hacer que las matronas pasantes vivan, durante un breve tiempo, una situación ficticia en pequeño grupo y en directo. El segundo contexto tiene la particularidad de proponer espacios de formación diferentes (video-formación, simulaciones y conducción de carruajes) y de extenderse durante un período largo ( 6 meses). El interés de reunir estas dos investigaciones radica en la complementariedad que ofrecen: la primera se centró en la actividad de observación en situación de visualización; la segunda buscó rastrear las transformaciones entre los diferentes contextos de formación incluyendo visualizaciones.

\subsection{Simulación en alta fidelidad realizada en directo sobre casos extraordinarios}

\subsubsection{Inmersión mimética, indagación y juego}

El primer momento seleccionado se sitúa durante una sesión cuyo objetivo es desarrollar competencias técnicas y no técnicas que contribuyan a resolver de manera adecuada la reanimación del recién nacido. Por razones organizacionales, la proyección de la filmación en la sala de debriefing se inició antes de que comenzara la sesión, es decir, antes de que las estudiantes actrices de la situación simulada entren en escena. Tres estudiantes están ahí como observadoras. Ellas anticipan que la situación preparada por las formadoras expone a las actrices a tener que resolver una complicación obstétrico-pediátrica durante un parto, sin conocer su naturaleza : "los guiones de simulación implican tener que manejar una urgencia, situaciones inhabituales y un poco estresantes, no se trata de fisiología". En cuanto comienzan a emitirse las cuatro entradas de video, que muestran diferentes planos del entorno simulado (Figura 11), ellas miran la pantalla. 
Figura 11 : Proyección fílmica, con cuatro entradas de video dei entorno simulado

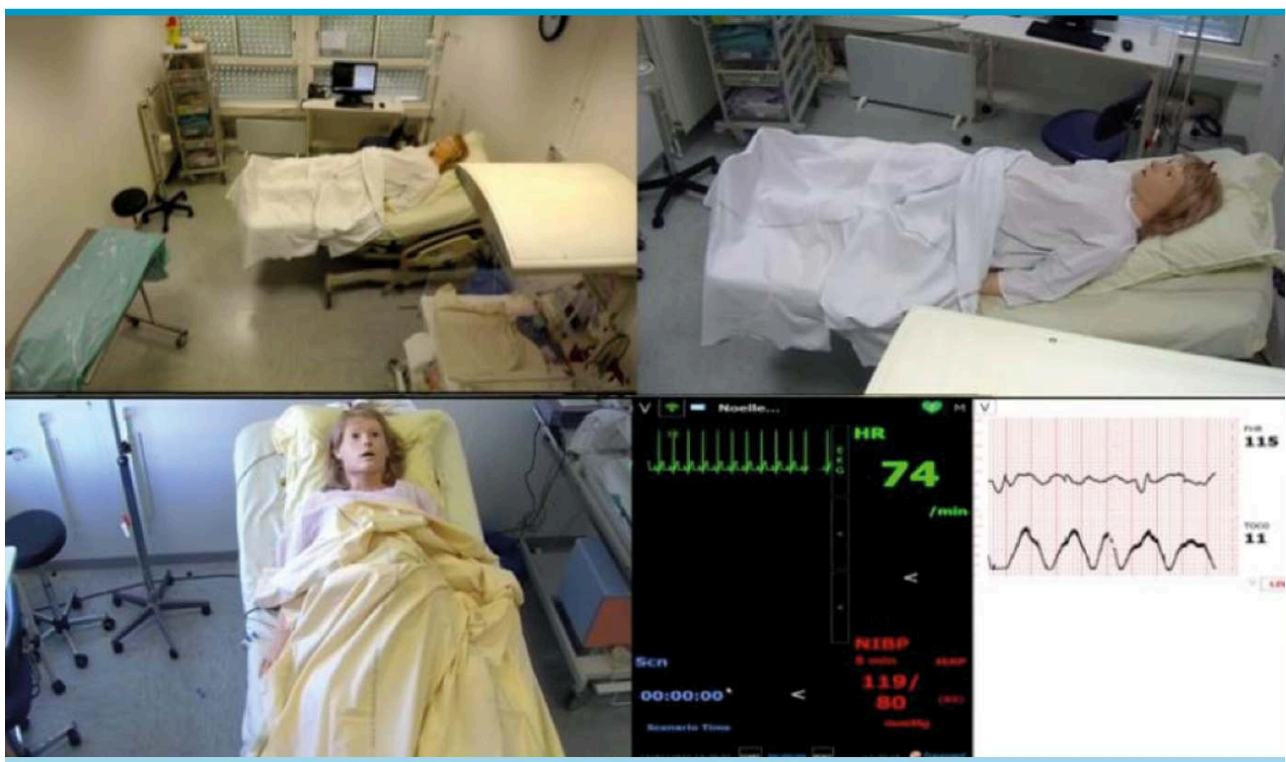

Figura 11: Proyección fílmica, con cuatro entradas de video del entorno simulado. Figure 11: Filmic projection with four video inputs of the simulated environment.

Figura 11 : Proyección fílmica, con cuatro entradas de video dei entorno simulado

40 Estelle visualiza el ritmo cardíaco fetal (RCF) : "ahí, la tele se enciende y vi el ritmo [...]" [U. 2.2]. Se queda boquiabierta (impulse [U.1.1]) ante el descubrimiento del ritmo (Figura 12) que se impone a su percepción: "nos hace reaccionar" (manifestación de una pregnancia [U.1.1]) y provoca estupefacción : "Estoy choqueada".

Figura 12 : Extracto fotográfico de la actividad evidente de Estelle

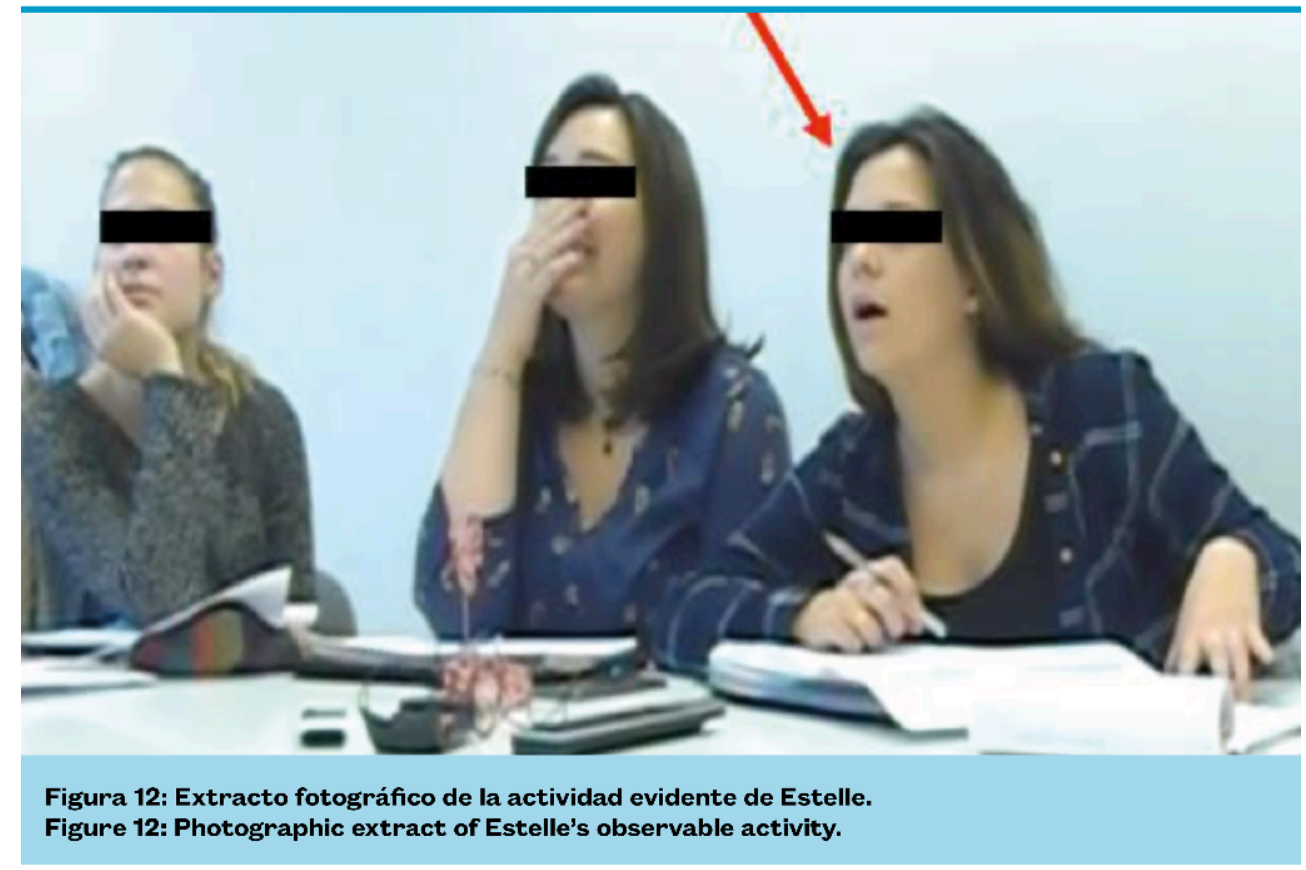

Figura 12 : Extracto fotográfico de la actividad evidente de Estelle 
Estelle siente empatía por el feto: “iAy! Me preocupa" (sentimiento [U. 2.1]), identificando una alteración de su bienestar : "el bebé no está bien desde hace un rato, aún antes de que todo comience" (discurso privado emergente [U. $3^{*} 1$ ]. Percibe la situación como inestable para el bebé que va a nacer y construye el problema planteado por el guión. Se sumerge en la situación y pronostica la actividad que imagina tener que desplegar en la situación visualizada : "está sufriendo [...] habrá que hacer una reanimación del recién nacido" (acción simbólica [U. 3*2]), para estabilizar la situación, luego, en un segundo tiempo, pone a prueba la fiabilidad de su hipótesis (auto-reflexión [U 3*3] (Anexo 1). Se embarca entonces en una actividad de indagación (Dewey, 1993) y adopta una postura distanciada, analítica, de la situación. Explora el entorno simulado : "miro las cuatro pantallas", dirige su observación al acondicionamiento del espacio dedicado a la reanimación del recién nacido (impulso [U.1.1]') y lo compara con las sesiones pasadas: "la mesa de reanimación no está como de costumbre" (acción [U.2.2]'). Se sorprende al ver que "está desplegado sobre la mesa un lugar destinado a secar al recién nacido" y se dice que necesariamente será utilizado durante la sesión (discurso privado emergente [U. $\left.\left.3^{*} .1\right]^{\prime}\right)$. Comparte los indicios seleccionados con las otras observadoras presentes : "mira, la mesa está abierta" (comunicación [U 3*.2]) lo que da cuenta de la dimensión cooperativa de la actividad de indagación. Hace dialogar a los elementos seleccionados con su sugerencia que aparece entonces como la solución a la situaciónproblema planteada por los formadores: "cuando veo eso, me digo va a haber una reanimación" (auto-reflexión [U 3*3]') (Anexo 2). La comprensión de la situación problema es acompañada por la continuidad de la experiencia mimética inicial con una proyección enfática de sí en el otro, el feto, pero también en las actrices (sentimiento [U 2.1]") por la identificación de nuevas indeterminaciones en cuanto al devenir del niño y en cuanto a la pertinencia de las acciones llevadas a cabo por sus pares en situación (discurso privado emergente [U 3*.1] "). En efecto, la observación se desarrolla en directo, lo que implica para Estelle ser testigo, sin poder sustraerse a ello, de una situación de simulación sin montaje, ni elipsis temporal, que puede hacerle ver lo inesperado, lo imprevisible (Jost, 2015) : "no estoy cómoda, sé que va a ir mal para el bebé, temo ver lo que va a ocurrir y cómo van a manejar la situación". Se prepara para vivir indirectamente una situación inédita. Adopta una actitud lúdica [15] (Henriot, 1983) considerando que la situación en la que está participando es incierta.

\subsubsection{Empatía, compromiso corporal y evaluación}

El segundo momento elegido se sitúa en el momento de la expulsión del feto durante una sesión de simulación llamada "hemorragia del parto" (figura 13). 
Figura 13 : Filmación proyectada dei entorno simulado

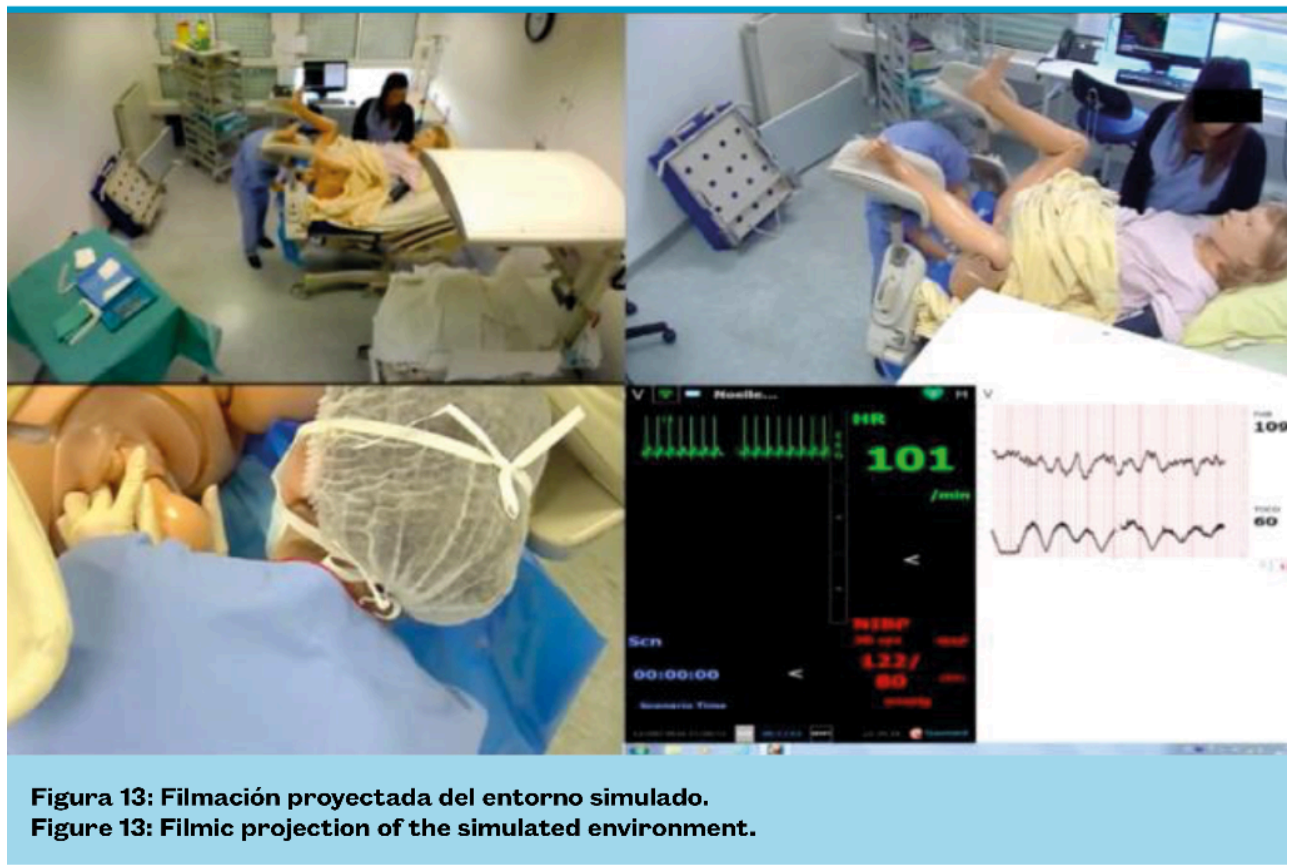

Figura 13 : Filmación proyectada dei entorno simulado

Laurène y otras dos observadoras conducen en forma conjunta la actividad de indagación destinada a descubrir la situación-problema prevista por las formadoras. Dado que el parto y la expulsión habían sido evaluados hasta ese momento como fisiológicos, Laurène no consigue ver en la situación observada indicios predictivos de la complicación clínica esperada. Esta indeterminación prolongada crea suspenso : "la espera es tan larga que es horrible de decir, pero quiero de verdad que pase algo". En el instante considerado, mira las maniobras de desprendimiento fetal realizadas (acción [U 2.2]) : "Miro abajo a la izquierda lo que hace, los gestos". Constata que el feto no se desprende (acción simbólica [U 3*2]) : "está atascado el pobrecito" y se siente mal por el feto (sentimiento [U 2.1]), pero también por la actriz en la situación : "hace lo que puede con el maniqui" (Anexo 3). La inmersión empática la lleva a sentir la incomodidad vivida por otro, a adoptar la perspectiva visual y espacial de la actriz, por una trasposición del punto de vista egocentrado en el cuerpo de la persona observada y por la medida de las diferencias que contribuyen a no identificarse con ella. Laurène piensa que la maniobra de recuperación no es óptima (discurso privado emergente [U $\left.3^{*} 1\right]$ ) : "no lo recuperó a decir verdad". A fin de darle un significado a los acontecimientos observados y verificar su hipótesis, se pone ficcionalmente en situación ante la parturienta (tropismo [U 2.1]') : "ahí estoy delante del perineo", se levanta y realiza la maniobra observada antes (Figura 14) sin que haya contacto efectivo con el feto (acción [U 2.2]') (Anexo 4). 


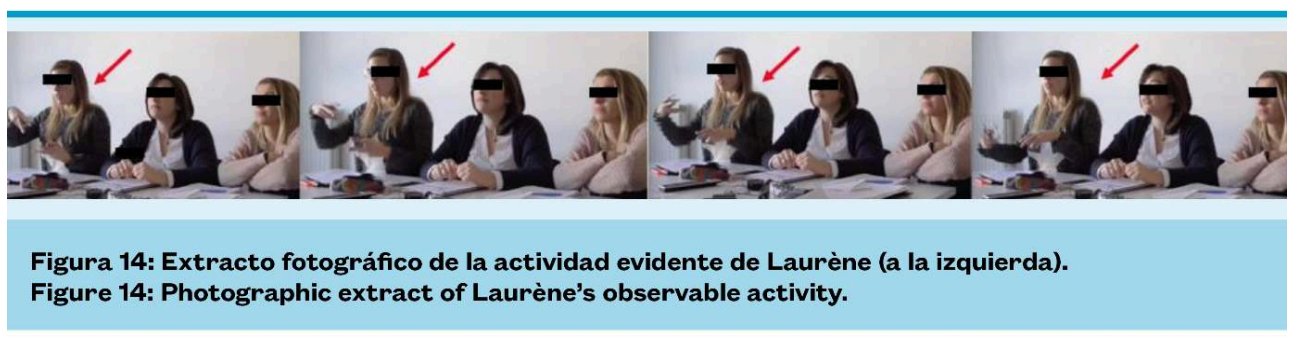

Figura 14 : Extracto fotográfico de la actividad evidente de Laurene (a la izquierda)

En este último caso (ver 3.3), nos interesamos en la situación de visualización de una pasante-conductora de carruajes. Las experiencias miméticas no sólo transforman la actividad de visualización de los pasantes, sino que tienen un efecto sobre su actividad de conducción. La investigación sobre el aprendizaje-desarrollo de los conductores ilustra esas transformaciones en un período largo de tiempo (6 meses). Notamos en su actividad experiencias miméticas de distinto orden. Esas experiencias tienen la característica de establecer una tensión entre lo que la pasante percibe de su actividad como conductora de carruajes y lo que percibe de la actividad de otros conductores. Las transformaciones vividas a partir de la visualización repercuten en los días posteriores a la sesión de video-formación: charlas con los formadores, continuación de la indagación, nueva sensación al conducir. 


\subsubsection{Comportamiento inmersivo y toma de conciencia}

Al navegar libremente por la plataforma de video-formación, la pasante selecciona un video sobre el tema "comunicación". La presencia de las palabras "contacto" y "equilibrado" en el título la interpela. Escucha en segundo plano la voz de su formador como un eco imaginario : "Vincent me hace/me dice a menudo : y ahí, re-equilibras tu caballo y no siempre entiendo". Dándole inicio al video, ella espera respuestas a esta cuestión del equilibrio del caballo. El comienzo del video la hace proyectarse a bordo de un carruaje en una pequeña ruta de campo. Es agradable. Su cuerpo se pone en movimiento balanceándose (Cuadro 1).

\section{Cuadro 1 : Transcripción textual de la pasante a propósito de su balanceo corporal}

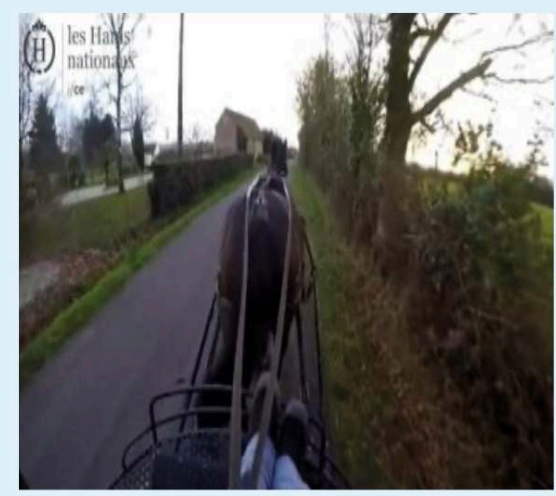

(...) es la manera de seguir la cosa, me gusta la música de los cascos (...) Además pienso que eso me ayuda también a visualizar, a visualizar, ehhh, al conductor.

(...) de ser como si fuera yo, ves, de visualizar dónde anda con su tac, tac, tac del caballo. (...) En sus manos, en su vehículo. (...) De meterme en realidad... en el movimiento de él... Más en el movimiento percibido que en el movimiento de él. Es decir, no un movimiento que él enviaría sino solo un movimiento que él seguiría. En relación al tac, tac de su caballo. (...) Verdaderamente de estar en eso, de seguir... De ser llevado (...) el ambiente cuenta. Pero el ambiente de... eso, de seguir a tu caballo. Pero no es porque te digas "sigo a mi caballo" (...) Es que te dejas llevar, no es voluntario. (...) sin pensar hacia dónde te lleva esa música.

Cuadro 1: Transcripción textual de la pasante a propósito de su balanceo corporal.

Table 1: Verbatim transcript of the trainee about her corporal rocking.

Cuadro 1 : Transcripción textual de la pasante a propósito de su balanceo corporal

El ruido de los pasos del caballo enganchado es percibido por la pasante como una melodía. A pesar del hecho de estar sentada frente a la pantalla de un ordenador, Nadège vive una inmersión mimética intensa : atraviesa imaginariamente la pantalla, proyectándose involuntariamente en lo que siente el cuerpo del conductor del video. Esa proyección no es visual, es un movimiento interno. En cambio, su reacción corporal es visible a través de un balanceo acompasado.

El análisis de ese momento permite construir el signo siguiente : (Cuadro 2). La pasante vive un impulso [U. 1.1] acompañado por un sentimiento agradable [U. 2.1] y una reacción corporal [U.2.2]. El elemento significativo que forma parte de ese signo es un representamen del orden de la emergencia de una forma global [R.2.1]. Este se ancla en un conjunto de cualidades particulares : la visualización de un entorno y una música agradables. Subyace un representamen del orden de la aparición de un fondo [R.1.1]: un ambiente agradable. 
Cuadro 2 : Hexatomia de la $U$ de un signo

\begin{tabular}{|c|c|c|c|c|c|}
\hline $\begin{array}{l}\text { Unidad de } \\
\text { curso de } \\
\text { experiencia }\end{array}$ & $\begin{array}{l}\text { Represen- } \\
\text { tamen }\end{array}$ & Compromiso & $\begin{array}{l}\text { Actualidad } \\
\text { potencial }\end{array}$ & Referencial & Interpretante \\
\hline $\begin{array}{l}\text { [U.1.1] } \\
\text { Impulso: } \\
\text { causado por } \\
\text { la música de } \\
\text { los cascos del } \\
\text { caballo } \\
\text { [U.1.2] } \\
\text { Sentimientos: } \\
\text { "Adoro el } \\
\text { ruido de los } \\
\text { cascos" } \\
\text { Curiosidad } \\
\text { [U.2.2] } \\
\text { [re]acción: } \\
\text { sigue el trote } \\
\text { del caballo } \\
\text { balanceando } \\
\text { su cuerpo } \\
\text { siguiendo el } \\
\text { ritmo. }\end{array}$ & $\begin{array}{l}\text { [R.1.1] } \\
\text { un ambiente } \\
\text { agradable } \\
\text { [R.2.1] } \\
\text { emergencia } \\
\text { de una } \\
\text { forma global: } \\
\text { musicalidad } \\
\text { del ruido de } \\
\text { los cascos } \\
\text { "tac, tac, tac, } \\
\text { tac" }\end{array}$ & $\begin{array}{l}\text { Descubrir } \\
\text { el video } \\
\text { seleccionado } \\
\text { Encontrar } \\
\text { elementos que } \\
\text { abren pistas } \\
\text { de trabajo: } \\
\text { buscar } \\
\text { respuestas, } \\
\text { elementos } \\
\text { de trabajo, } \\
\text { encontrar } \\
\text { cosas para } \\
\text { probar y } \\
\text { testear. } \\
\text { Comprender } \\
\text { cómo hacer } \\
\text { para re- } \\
\text { equilibrar un } \\
\text { caballo y cómo } \\
\text { ver un caballo } \\
\text { en equilibrio/ } \\
\text { desequilibrio }\end{array}$ & $\begin{array}{l}\text { "video "Hacia } \\
\text { un contacto } \\
\text { equilibrado" } \\
\text { " } \\
\text { en acuerdo } \\
\text { con el titulo; } \\
\text { aportando } \\
\text { informacion } \\
\text { es visuales; } \\
\text { aportando una } \\
\text { explicación } \\
\text { "yo" } \\
\text { descubriend } \\
\text { o el video; } \\
\text { reteniendo } \\
\text { informacion es } \\
\text { ofrecidas por } \\
\text { el video. }\end{array}$ & $\begin{array}{l}\text { [yo] no sé } \\
\text { bien cómo } \\
\text { mantener } \\
\text { un caballo } \\
\text { en equilibrio; } \\
\text { no entiendo } \\
\text { cuando el } \\
\text { formador } \\
\text { me dice que } \\
\text { re-equilibre } \\
\text { mi caballo } \\
\text { [formador] } \\
\text { dice a } \\
\text { menudo: "ahi } \\
\text { re- equilibra } \\
\text { tu caballo" } \\
\text { [videos } 1 \& 2 \text { 2] } \\
\text { son esencial- } \\
\text { mente visua- } \\
\text { les: tienen un } \\
\text { título desfasa- } \\
\text { do del conteni- } \\
\text { do. }\end{array}$ & $\begin{array}{l}\text { [1.2.1] } \\
\text { Refuerzo de } \\
\text { tipo: [música } \\
\text { de los cascos] } \\
\text { es agradable }\end{array}$ \\
\hline
\end{tabular}

Cuadro 2 : Hexatomia de la $U$ de un signo

50 En el momento en que su cuerpo se balancea, la pasante no tiene conciencia de balancearse al ritmo de los pasos del caballo. No lo piensa y lo hace sin prestar atención: "Pero el ambiente de..., de seguir a tu caballo. Pero no es porque te digas 'sigo a mi caballo"'. De la misma manera, en ese momento en que la pasante se deja invadir por la musicalidad, los puntos de apoyo de la conciencia se desvanecen y su compromiso anterior (encontrar pistas de trabajo) se esfuma temporalmente ante una forma de escucha-placer, sin intención particular. En ese instante, la pantalla del ordenador y la situación de visualización [ $\left.{ }^{17}\right]$ desaparecen momentáneamente. La pasante dice sentirse "transportada" por el "movimiento experimentado" por el cuerpo del conductor del video que "parece estar siguiendo el tac tac de su caballo". En esta percepción-placer de la pasante que provoca una experiencia mimética corporal, el cuerpo del conductor concuerda/se sincroniza con el trote del caballo. La naturaleza de ese signo es de tipo pasional, tal como se lo puede encontrar en la actividad de contemplación (Theureau, 2004). Ese placer, esa escucha, ese balanceo bajo la forma de dejarse llevar difícilmente se dan en un contexto de conducción real en función de la dinámica y la intensidad propias de la actividad, sobre todo en el caso de principiantes. En la conducción de un carruaje, los compromisos ligados a la responsabilidad, el control, la seguridad, la aplicación correcta del gesto, le sacan ventaja a las otras preocupaciones en el curso de la acción. En esas situaciones, la musicalidad de los pasos del caballo, la escucha placentera, el sentimiento de armonía están ausentes. Por el contrario, el contexto simulado ofrecido por el video permite la exploración de esa vivencia pasional. La intervención de la investigadora saca a la pasante de esa experiencia mimética de primer grado (experiencia mimética de 1er grado = sin U simbólica), interrumpiendo su curso de la acción contemplativo. 
51 El video avanza y la pasante sigue mirando. Lo que se le aparece entonces de manera significativa ya no son los pasos del caballo y su musicalidad sino la ausencia de la voz del conductor. En ese momento, detecta una disparidad entre el contenido del video y el tema "comunicación". Sus compromisos relativos a la apertura de pistas de investigación para su conducción vuelven al primer plano de su curso de la acción. La evolución de su acción de visualización está justificada por la toma de distancia entre la inmersión sensorial mimética y la toma de conciencia de una ausencia extraña: “todavía no se escuchó el sonido de su voz" (Cuadro 3).

Cuadro 3 : Transcripción textual de la pasante relativa a la emergencia de una investigación

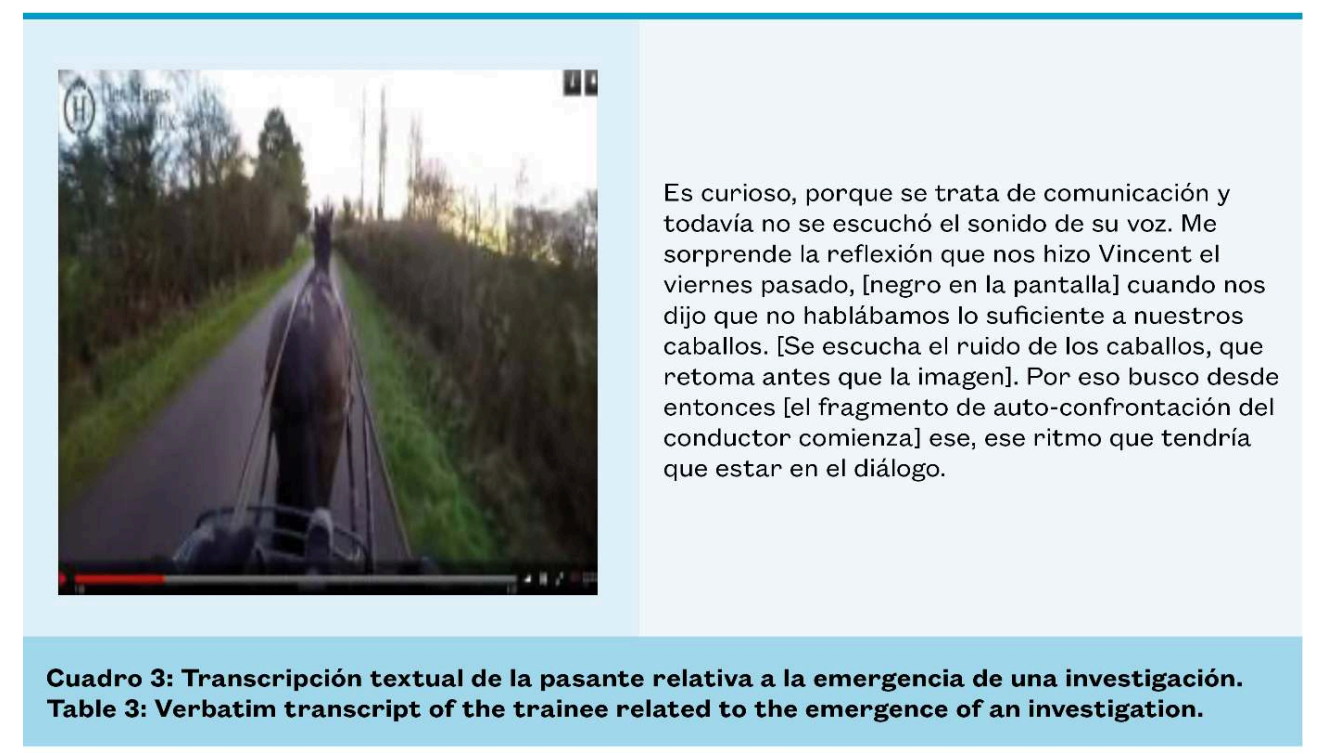

Cuadro 3 : Transcripción textual de la pasante relativa a la emergencia de una investigación

El mutismo del conductor en el video sorprende a la pasante pues, en el curso de vida relativo a la formación en la conducción de carruajes, está tratando de apropiarse de la noción de comunicación con un caballo enganchado. Esta comunicación pasa principalmente por la acción de las manos del conductor y, de manera complementaria, por la voz y el látigo. Sabe que debe trabajar en ello para actuar de manera adecuada a los requerimientos culturales. Distanciándose de su vivencia de inmersión contemplativa/pasional, la pasante constata una paradoja entre el tema "comunicación" del video y el contenido "mudo" del video. El contraste entre el anuncio del tema "comunicación", que genera una espera del uso de la voz por parte del conductor, y el silencio del mismo conductor, crea en Nadège una extrañeza [U.2.1] (tropismo), algo inesperado que abre una intriga (Anexo 5). No percibió el silencio inmediatamente dado que el trote de los pasos del caballo había invadido anteriormente la conexión de la pasante con el video. Ahora que se le revela ese conductor mudo, lo inesperado hace emerger una experiencia ya vivida anteriormente por la pasante en relación al uso de la voz para comunicarse con el caballo (J-4). La experiencia mimética de haber vivido situaciones similares entre el conductor que no le habla a su caballo y ellos, los pasantes, a los que el formador les dice que no hablan lo suficiente a sus caballos, reactiva una indagación planteada precedentemente : ¿cómo establecer una comunicación verbal suficiente con su caballo? 


\subsubsection{La experiencia del otro que transforma la experiencia del pasante que visualiza}

53 La segunda parte del video presenta una conversación del conductor que explica la conducción que acaba de visualizar la pasante. Hasta ese momento, el contenido del video, considerado potencialmente útil por la pasante, era principalmente visual y sonoro. Lo que provocó que se sumergiera primero en una actividad de observacióncontemplativa, y luego, en una de observación-investigación (de indicios visuales y sonoros). El cambio de contenido, orientado ahora a los comentarios del conductor, coloca a la pasante en una actividad de escucha-comprensión y de búsqueda de nuevos indicios, esta vez discursivos. En esta actividad de escucha, observamos nuevas formas de experiencias miméticas. La interacción de la pasante con los comentarios del conductor del video produce diferentes efectos: cuestionamiento abierto a un conductor ausente, reconocimiento de un problema compartido con el conductor del video, repetición en eco de las palabras del conductor del video que llaman su atención, reproducción selectiva del comienzo del video (que le permite ver lo invisible de la primera visualización) (Cuadro 4).

Cuadro 4 : Interacciones de la pasante en la situación de visualización mediada por la investigadora

\begin{tabular}{|c|c|c|c|c|c|}
\hline (1) & $\begin{array}{l}\text { Voy } \\
\text { realmente a } \\
\text { poner peso. Y } \\
\text { luego, cuando } \\
\text { me suelte, yo } \\
\text { diré, la mano, } \\
\text { en ese mismo } \\
\text { momento, } \\
\text { mi mano va a } \\
\text { avanzar }\end{array}$ & $\begin{array}{l}\text { Trato de } \\
\text { tenerlo } \\
\text { derecho. Ahí } \\
\text { se ve bien que } \\
\text { se desplaza } \\
\text { ligerament } \\
\text { e hacia la } \\
\text { izquierda }\end{array}$ & $\begin{array}{l}\text { Esta vez, voy } \\
\text { realmente a } \\
\text { retrotraer } \\
\text { mi mano } \\
\text { derecha, } \\
\text { se ve bien } \\
\text { ves, porque } \\
\text { mi mano } \\
\text { desaparece } \\
\text { un poco de la } \\
\text { imagen }\end{array}$ & $\begin{array}{l}\text { (el conductor } \\
\text { continúa con } \\
\text { sus comenta- } \\
\text { rios) }\end{array}$ & $\begin{array}{l}\text { Ahí se ven } \\
\text { bien mis } \\
\text { manos que } \\
\text { van para } \\
\text { atrás y que } \\
\text { vuelven para } \\
\text { adelante, así } \\
\text { es, } \\
\text { y ahí estoy } \\
\text { verdaderame } \\
\text { nte } \\
\text { conversando } \\
\text { con él (...) }\end{array}$ \\
\hline Efecto & $\begin{array}{l}\text { Interrogato- } \\
\text { rio }\end{array}$ & $\begin{array}{l}\text { Lo } \\
\text { compartido }\end{array}$ & $\begin{array}{l}\text { Reproducción } \\
\text { solicitada }\end{array}$ & $\begin{array}{l}\text { Reproducción } \\
\text { diferida }\end{array}$ & $\begin{array}{l}\text { Repetición en } \\
\text { eco }\end{array}$ \\
\hline $\begin{array}{l}\text { Pasante } \\
\text { visualizando }\end{array}$ & $\begin{array}{l}\text { ¿Entonces } \\
\text { pones peso } \\
\text { en tí/ Retro- } \\
\text { trayendo tu } \\
\text { mano? }\end{array}$ & $\begin{array}{l}\text { Si, es mi } \\
\text { problema } \\
\text { [murmura } \\
\text { ndo] }\end{array}$ & $\begin{array}{l}\text { ¿Podemos } \\
\text { verlo otra } \\
\text { vez? }\end{array}$ & $\begin{array}{l}\text { Volveré } \\
\text { a verlo } \\
\text { después, } \\
\text { cuando él } \\
\text { haya ter- } \\
\text { minado de } \\
\text { hablar. }\end{array}$ & $\begin{array}{l}\text { "estoy } \\
\text { conversando } \\
\text { con él» } \\
\text { "no hay } \\
\text { un solo } \\
\text { momento } \\
\text { en que yo no } \\
\text { haga nada» }\end{array}$ \\
\hline $\begin{array}{l}\text { Cuadro 4: In } \\
\text { investigador } \\
\text { Table 4: Inte }\end{array}$ & ciones de la & ite en la si & Wation & me & \\
\hline
\end{tabular}

Cuadro 4 : Interacciones de la pasante en la situación de visualización mediada por la investigadora

Después de ver el video, la pasante vuelve a reproducirlo: “imuéstrame, ahora quiero volver a ver!" Busca volver a ver el desequilibrio del caballo del que habló el conductor : "Es excitante, porque sé que ahora voy a ver más cosas!" Percibe de manera diferente la actividad de conducción del conductor, ayudada por sus comentarios, relatos, demostraciones: "Ah sí, es eso. Ves, es ahí donde el caballo giró/ves cómo gira un poco la cabeza. Y donde él, de pronto, le marca a la derecha". Esta secuencia es acompañada por dos 
principales transformaciones de conocimientos-tipo presentes en la pasante : la noción de peso y la noción de conversación con las manos. Descubre un nuevo modo de hablar del contacto : en términos de peso y no sólo de tensión. Aprende que al llevar la mano hacia atrás, el conductor dice algo con la rienda. Es la asociación de su compromiso y sus percepciones en el discurso del conductor del video validadas por una nueva visualización esclarecedora, lo que permite la transformación del referencial de la pasante. Este aprendizaje es significativo en su curso de vida: va a reorientar sus preocupaciones, percepciones y búsquedas de acciones en la conducción de carruajes.

"Cuando lo escucho decir "estoy conversando con él" pese a que no intercambió ni una palabra con su caballo, y que para él "conversar" está en sus manos, ves, a nivel del contacto, eso te abre perspectivas, ves tus manos que sirven para decir/porque finalmente, tus manos, tienes la impresión al cabo de un rato en el carruaje, que estás ahí para imponer después de todo para, para decir lo que hay que hacer en todo momento. Lo que es verdad. Pero cuando conversas, no tienes esa impresión de dar una orden. De pronto, tienes la impresión de buscar el contacto y de estar en concordancia con tu caballo".

\subsubsection{Prolongaciones fuera de la experiencia de video-formación : líneas de investigación (reflexivas, corporales y perceptivas), intercambios con los formadores}

Las prolongaciones fuera de la situación de video-formación se observan en el curso de la vida de la pasante en forma de reaperturas de historias. En los siguientes dos ejemplos se puede ver la transformación de sus saberes.

La historia de "estimular con el látigo" y la historia del "peso" reaparecen al día siguiente de la proyección del video durante una sesión de conducción con un formador. Se trata de dos historias que quedaron en suspenso durante las visualizaciones. Es decir, que abrieron pistas para la transformación de su práctica para cuya confirmación, la pasante necesita tener la validación del formador. Al interpelar a sus formadores, se asegura de actuar conforme a lo que se espera de la formación. La historia del látigo surge mientras está conduciendo. El formador confirma su idea de "estimular con el látigo" (Cuadro 5). Suponemos que la pasante legitima esta historia como tipo de acción válida con el látigo. 

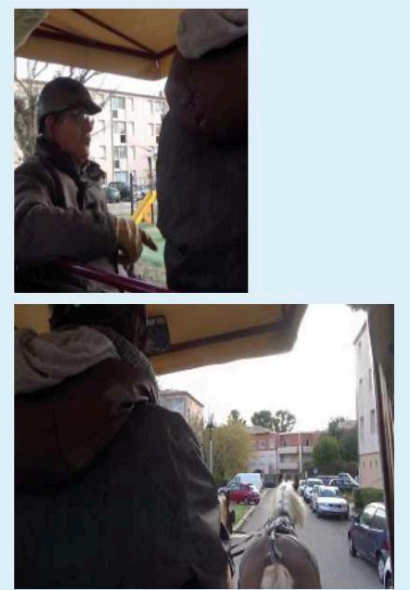

Nadège llama repetidas veces a Arion. Louis le

dice: Dejas de lado las riendas y te manejas con el látigo.

$\mathrm{N}$ : ¿Entonces lo estimulo así?

L: Eso mismo.

Cuadro 5: La historia del látigo reaparece al día siguiente de la visualización.

Table 5: The story of the whip re-emerging the day after the viewing-

Cuadro 5 : La historia dei látigo reaparece ai día siguiente de la visualización

La historia del peso dio lugar a una conversación con el formador después de la conducción. Nadège escucha los matices aportados por el formador ; sin embargo, esta interacción no la deja del todo satisfecha y deja la historia del peso en suspenso. Piensa continuar indagando sobre esa historia del peso que la acompañará hasta el final de la formación. Dos días después, mientras conduce, surge una transformación importante. Por primera vez, presta atención a una sensación de liviandad en las riendas, cuando hasta ese momento lo que llamaba su atención era lo pesado de las mismas. Se da cuenta de que puede conducir sus caballos sin forzar y sin peso. Este elemento constituye un aprendizaje crucial en la formación del conductor de carruajes. Las experiencias miméticas vividas durante las proyecciones de los videos en los que se ve a otros conductores movilizaron, en la experiencia entera de la pasante, imaginaciones sensoriales diversas : visuales, auditivas y somáticas. Esas experiencias pudieron luego prolongarse en otros contextos : en situación de conducción o en conversaciones con los formadores. Nuestros resultados (Secheppet, 2020) muestran la importancia de la complementariedad de las experiencias sensibles y verbalizadas en los procesos de apropiación, así como la necesidad de idas y vueltas entre experiencias de la práctica y experiencias de distanciación permitidas por la interacción con la actividad de otros conductores, con los formadores o con otros pasantes.

\section{Discusión}

\subsection{Experiencia mimética, relación icónica y movimiento (juego)}

58 Con el fin de comprender, describir y explicar la experiencia mimética en situaciones de video-formación, examinamos una relación particular en el seno del acoplamiento actor-entorno : la relación de la experiencia uno mismo/otro constituida en la actividad mimética (Wulf, 2007). Esa relación incluye una bivalencia "similitud/diferencia" característica de la actividad de comparación (Poizat \& Goudeaux, 2014; Horcik, \& Durand, 2015). Esta bivalencia abre relaciones inéditas portadoras de desestabilización 
y de desarrollo para quienes están en formación. La relación de proximidad/distancia entre uno mismo y el otro no se limita sin embargo a una actividad de tipo reflexivo. Por el contrario, las primeras manifestaciones de esa relación son a menudo imprecisas, borrosas. Corresponden a impresiones, intuiciones, sensaciones, atracciones o rechazos. El punto común de esas primeras manifestaciones es su carácter poco determinado. La documentación de la hexatomia de la U nos permite poner en evidencia que la experiencia mimética se desarrolla a partir de una forma poco determinada ([U.1.1] y [U.2.1]) y se dirige hacia una forma mejor determinada, acompañada de simbología ([U.3*.2] y [U.3*.3]). Las unidades de experiencia indeterminadas son de índole degradada $\left.{ }^{[18}\right]$ y se muestran en una relación con el mundo de los sentidos, como una relación borrosa característica del ícono: “[...] El ícono no indica como lo hace el indicio, sino que sugiere, deja entender o percibir, pero como en algo borroso o incierto" (Fisette, 2012, p. 278, traducción libre). Esta relación es acompañada por un débil grado de certeza y de estabilidad. Las características sensitivas y poco determinadas de la relación icónica explican el hecho de que esas experiencias subyacentes sean difíciles de documentar. Volvemos a encontrar ese carácter de poca determinación en los trabajos sobre la metáfora desarrollados por Durand et al. (2013): "Hay ahí un registro donde las significaciones están poco determinadas, donde las cosas significan otras cosas de manera equívoca, desinteresada, oscilante, placentera, errática. Son portadoras de concentraciones, desdoblamientos, desfasajes, desviaciones, descentraciones... en relación con un compromiso terminado y unívoco" (p. 55, traducción libre). Volvemos a sus observaciones: "La fecundidad de la metáfora para el aprendizaje se explica porque su significación establece una similitud nueva a través de una puesta en relación que estaba ausente previamente" (Ibid., p. 58, traducción libre). Pero antes de ser clara, esta relación es caótica. Extendemos la pista de la relación icónica abierta por esos autores, por el interés puesto en la hexatomia de la $\mathrm{U}$ y sus componentes poco determinados. Fisette (1998/1999) sugiere la idea de que la incertidumbre dejada por el ícono hace posible una "atenuación de la referencia" y por lo tanto, una apertura y una puesta en movimiento: eso crea un espacio de juego. Este espacio de juego es un espacio de acción potencial que permite el desplazamiento. Este desplazamiento puede ser una marcha atrás (forma de regresión) antes de provocar una extensión de la actividad. "Lo que la figura del ícono pierde en valor de verificabilidad, lo gana en poder de sugerencia ; en suma, hay una pérdida de comprensión, pero se gana en extensión" (Fisette, 2012, p. 278, traducción libre). De esta forma, el ícono aparece como un espacio de libertad para el imaginario que, a su vez, fragiliza y enriquece al signo. Poizat, Salini y Durand (2013) evocan una "modalidad icónica de significación" (p. 105) propicia para las relaciones miméticas y de aprendizaje. Por otra parte, Fisette (2012) subraya que el ícono apela a todos los sentidos : visual, sonoro, olfativo, táctil, gustativo. Gal-Petitfaux (2015) resaltó la importancia de esa inmersión sensorial en el marco de de la formación docente : "Esas herramientas [la video-formación] facilitaron un abordaje pragmático y encarnado de las situaciones de clase : los estudiantes primero identificaron, no ideas o conceptos, sino mundos vivos (con acontecimientos y actividades de trabajo) y mundos vividos (evocación de recuerdos profesionales)" (p. 16, traducción libre). Dado que la experiencia mimética se caracteriza por establecer una relación entre la actividad propia y la del otro, la misma es un registro de experiencia siempre singular en cuyo seno el compromiso de los actores en las situaciones es complejo. No existe experiencia mimética sin esa relación uno mismo-otro que es portadora de "transformaciones de la 
actividad debido a desfasajes, concentraciones, desdoblamientos, desviaciones, descentraciones, etc., que genera en relación con un compromiso finalizado y unívoco" (Ibid., p. 41, traducción libre). Los entornos de video-formación y/o de simulación proponen situaciones emblemáticas que hacen que aparezca dicha experiencia mimética.

\subsection{Intereses y límites de esos dispositivos de formación con fuerte potencial inmersivo}

59 La concepción de los tres dispositivos de formación presentados se caracteriza porque estos tienen en común la posibilidad de crear entornos de fuerte potencial inmersivo gracias a la utilización de artefactos video que constituyen propuestas o posibles de acciones simuladas, imaginadas para quienes están en formación. Las mediaciones fílmicas se presentan como vectores de inmersión (Schaeffer, 1999) que permiten por una parte transformar el entorno de quienes se están formando, ofreciéndoles la oportunidad de compartir el mundo de los actores observados, y por otra parte, perturbar su actividad. Los detonantes miméticos (circunscripción de una zona situacional de desempeño [U.1.1]) son inherentes al estatus semiótico de las secuencias ilustradas vistas en directo o en diferido ( $I b i d$.$) y al grado de familiaridad que el$ participante en la formación mantiene con la situación visualizada (Flandin et al., 2018). La focalización sobre aspectos de la práctica depende o bien de la iniciativa del aprendiente que navega en una plataforma y selecciona, según sus preocupaciones actuales, situaciones ordinarias pero que domina poco (actividad de conducción de carruajes), o incluso situaciones críticas (dificultades al inicio del curso), o bien impuesta por una visualización en directo de situaciones extraordinarias, con final incierto (hacerse responsable de un trabajo marcado por una asfixia fetal durante el parto). Sea cual fuere el contexto, el objetivo es similar : contribuir a un aprendizajedesarrollo que se traduzca en mejorar el desempeño cuando quienes están en formación se enfrenten a situaciones reales de trabajo, consideradas similares. De esta manera, esos dispositivos se inscriben: a) en un enfoque de desarrollo, es decir que están dirigidos a estimular la emergencia de cuestionamientos fuentes de adquisición "de nuevos modos de acción surgidos del patrimonio cultural profesional" (Durand, 2009, p. 98, traducción libre) y b) en un enfoque proscriptivo (todo lo que no está proscripto está autorizado) que se distancie de un enfoque normativo basado en la demostración de la actividad de un experto que apuntaría a "lo que hay que hacer" con el objetivo de una replicación (Leblanc, 2014). Para nosotros, un enfoque ajustado a normas dejaría poco espacio para la adopción de posturas miméticas que consisten en sumergirse en el mundo de los observados (Tropismo [U2.1]), y en expresar experiencias miméticas y ficcionales singulares, creativas y de apoyo para aprendizajes profesionales (Wulf, 2007). Según Wulf, "los procesos miméticos no son simples procesos de imitación, de reproducción o de impronta. Implican por el contrario personificaciones singulares, que dan lugar a las condiciones y a las diferencias individuales" (p. 23, traducción libre). Así, se pudieron identificar dos vectores de inmersión encastrados que muestran una oscilación constante de proximidad y distancia entre quienes están en formación y los observados. Por un lado, una posición de observación (Schaeffer, 1999) que muestra una inmersión perceptiva impersonal "veo y escucho lo que ve y escucha el observado", "recreo el mundo del observado", (Acción [U.2.2]), y por otro lado, una substitución de identidad (Ibid.) que traduce una 
vivencia por poder, "siento (Siento [U.2.1]) y hago como si fuera el observado" (Acción simbólica [U.3.*2]). La posición de observación se prolonga en una actividad de análisis (Ideación [U.3.*1]) y de evaluación de la situación visualizada y también con una puesta en relación entre la actividad imaginada que tendrá lugar y la de los observados (Autoreflexión [U.3.*3]). La substitución de identidad física "implica a la vez una identificación que personifica y una mímesis actancial" (Schaeffer, 1999, p. 253, traducción libre). Esta identificación alo-subjetiva actancial se manifiesta con reacciones emocionales de valencia positiva o negativa (Sentimiento [U.2.1]), e intencionales, puestas de manifiesto por la ejecución ficticia de acciones (desplazamientos, gestos imaginados o realizados), si bien no tienen incidencia efectiva en los contextos en los que se encuentran inmersos los participantes en la formación (Acción simbólica [U.3*.2]). Esas dos posturas merecen ser incentivadas; contribuyen a construir una reflexión profesional confrontando la práctica propia con la de otros y a identificar diferencias reales o de posibles inter o intra-actividades (Duboscq \& Clot, 2010 ; Muller \& Lussi Borer, 2018) (Auto-reflexiones [U.3.*3]), in fine a la producción de diferencias ya sea que las acciones sean imaginadas o efectivas (Wulf, 2007).

Así, esos dispositivos presentan muchos intereses educativos relativos a las experiencias miméticas y ficcionales: a) descubrir y/o experimentar situaciones profesionales complejas o excepcionales, b) "hacer surgir" a partir de diferentes experiencias vividas, preguntas cuya pertinencia es dictada por las significaciones construidas por el propio actor, c) aprehender y comprender de un modo diferente la complejidad de una situación de trabajo, d) atenuar las consecuencias de las acciones para poder liberarse de la presión de cualquier riesgo tanto para uno mismo como para un tercero, e) (re)activar estados emocionales, sensaciones, y f) comprometerse durante un período largo de tiempo [ $\left.{ }^{19}\right]$ a elaborar historias que constituyan un incentivo eficaz de aprendizaje-desarrollo.

61 Sin embargo, en nuestro rol de creadores de formación, es prudente prestar atención a algunos aspectos que pueden afectar el alcance transformador de tales entornos de video-formación. Por una parte, la capacidad de observar y analizar la característica pluridimensional de una situación profesional no es tan evidente. La observación puede asemejarse a una actividad de recopilación (Flandin et al., 2015), que consiste en ver, mirar, escuchar (Acción [U 2.2]). En ese caso, la actividad no se prolonga en acción simbólica ([U 3*.2]) ni en auto-reflexión ([U 3*.3]), lo que limita su valor formativo. Por otra parte, una secuencia visualizada de manera individual puede suscitar interrogantes sin respuestas (Ideación [U 3.*1]), o incluso puede suceder que en la observación colectiva aparezcan construcciones colegiadas erróneas. Por último, los estados emocionales (Sentimiento [U2.1]) que surgen de las experiencias miméticas y ficcionales pueden ser de carácter compasivo y conducir a un bloqueo, una paralización en la conducción de la actividad (Leblanc \& Blanes-Maestre, 2018). Si esas experiencias forman parte de una concientización de su propia gestión emocional, por ejemplo la ausencia de empatía (Berthoz, 2003), pueden afectar negativamente el sentimiento de eficacia personal, y por consiguiente, pueden llegar a inhibir la acción en situaciones similares posteriores (Bandura, 2007). Para subsanar esas limitaciones, se pueden movilizar un cierto número de recursos. En primer lugar, es posible establecer un debriefing para acompañar los procesos de tipicalización (subsanar, reforzar) y para asegurar el paso de la especificidad de la situación observada-vivida a una mayor genericidad (transferibilidad), estimulando una postura de auto y de alo-análisis así 
como el debate en caso de observación colectiva (Bouchot, 2019). En segundo lugar, cuando los equipamientos técnicos lo permitan, repetir las experiencias de visualización de una misma filmación contribuiría a provocar (o no) nuevas perturbaciones y a acompañar nuevas transformaciones [ $\left.{ }^{20}\right]$ (o refuerzos). Por último, buscar la manera de tener acceso a las preocupaciones de los participantes en la formación, de detectar y seguir las indagaciones y las historias que ellos elaboran a lo largo de períodos más o menos largos dentro o fuera de esos espacios de inmersión debe permitir anticipar situaciones de formación y ayudar a las personas a "conectar sus experiencias" (Saury et al., 2013).

Notas/Notes

\section{BIBLIOGRAFÍA}

Azéma, G. (2015). L'improvisation selon les enseignants entrant dans le métier. Une approche en anthropologie cognitive. Thèse de doctorat non publiée, Université Montpellier 3.

Azéma, G., Secheppet, M., \& Mottaz, A-M. (2020). Envisager une ethnographie énactive ? Réflexions illustrées. Activités, 17(2). https://doi.org/10.4000/activites.5407

Bandura, A. (2007). Auto-efficacité : Le sentiment d'efficacité personnelle. Louvain-la-Neuve, Belgique : De Boeck.

Barbier, J-M. (2009). Voies pour la recherche en formation. Éducation et didactique, 3(3), 120-129.

Berthoz, A. (2003). La décision. Paris, France : Odile Jacob.

Bonnemain, A., Perrot, E., \& Kostulski, K. (2015). Le processus d'observation, son développement et ses effets dans la méthode des autoconfrontations croisées en clinique de l'activité. Activités, 12(2), 98-124. http://www.activites.org/v12n2/v12n2.pdf

Bouchot, H. (2019). Observer autrui lors de séances de simulation haute-fidélité : Une activité mimétique et ludique portée par en en-jeux sérieux. Thèse de doctorat en Sciences de l'Éducation et de la Formation, Université Montpellier.

Bouchot, H., \& Leblanc, S. (2019). Observer ses pairs lors de séances de simulation haute-fidélité : une activité de nature ludique portée par des en-jeux sérieux. Activités, 16(2). http:// journals.openedition.org/activites/4425

Cahour, B. (2006). Les affects en situation d'interaction coopérative : proposition méthodologique. Le Travail Humain, 69(4), 379-400. doi :10.3917/th.694.0379.

Dewey, J. (1993). Logique : La théorie de l'enquête (G. Deledalle, Trad.). Paris : PUF.

Duboscq, J., \& Clot, Y. (2010). L'autoconfrontation croisée comme instrument d'action au travers du dialogue : objets, adresses et gestes renouvelés. Revue d'anthropologie des connaissances, 4(2), 255-286. doi :10.3917/rac.010.0255.

Durand, M. (2008). Un programme de recherche technologique en formation des adultes : une approche enactive de l'activité humaine et l'accompagnement de son apprentissage/ développement. Éducation \& Didactique, 3(2), 69-93. 
Durand, M. (2009). La conception d'environnement de formation sous le postulat de l'enaction. In M. Durand \& L. Filliettaz (Eds.), Travail et formation des adultes (pp. 191-225). Paris, France : PUF. Durand, M. (2013). Construction of dispositions and development of human activity. A theorical framework illustrated by the case of a novice manager. International Journal of Lifelong Education, 32(1), 39-55.

Durand, M., Goudeaux, A., Horcik, Z., Salini, D., Danielan, J., \& Frobert, L. (2013). Expérience, Mimesis et apprentissage. In L. Albarello, J.-M. Barbier, E. Bourgeois \& M. Durand (Eds), Expérience, activité, apprentissage (p. 39-64). Paris : PUF. http://www.cairn.info/experienceactiviteapprentissage--9782130619758-page-39.htm

Fisette, J. (1998/1999). Parler du virtuel. La musique comme cas exemplaire de l'icône. Protée, 26(3), 45-54. https://constellation.uqac.ca/2367/1/Vol_26_no_3.pdf

Fisette, J. (2012). Courte lecture de la notion d'icône chez Peirce. Intellectica, 58(2), 277-284. https://intellectica.org/fr/courte-lecture-de-la-notion-d-icone-chez- peirce

Flandin, S., Leblanc, S., \& Muller, A. (2015). Vidéoformation “ orientée activité » : Quelles utilisations pour quels effets sur les enseignants. Analyse du travail et formation dans les métiers de l'éducation. Raisons éducatives, 19, 179-198.

Flandin, S., Leblanc, S., Muller, A., Roche, A., Blanes Maestre, C., Gal-Petitfaux, N., Lussi Borer, V., \& Ria, L. (2018). Une approche sémiologique de l'activité et de la vidéo-formation : Repères théoriques. In C. Gaudin, S. Moussay, S. Flandin, \& S. Chalies (Eds.), Vidéo-formation et développement de l'activité professionnelle enseignante (pp. 33-48). Paris : L'Harmattan.

Gal-Petitfaux, N. (2015). Faire de l'expérience vidéoscopée un moyen de formation au métier d'enseignant : l'appropriation d'un dispositif multimédia par des étudiants en éducation physique. Questions vives [en ligne], 24. http://journals.openedition.org/questionsvives/1854

Gaudin, C., Flandin, S., Moussay, S., \& Chaliès, S. (2018). Vidéo-formation et développement de l'activité professionnelle enseignante. Paris : L'Harmattan.

Henriot, J. (1983). Le jeu. Synonyme-S.O.R.

Horcik, Z., \& Durand, M. (2015). L'expérience mimétique dans l'apprentissage adulte : le cas des formations par simulation. Schweizerische Zeitschrift für Bildungswissenschaften, 37(1), 167-186.

Jost, F. (2015). La Télé-réalité : Grandeur et misère de la télé-réalité. Le Cavalier Bleu.

Kleiber, G. (1991). Prototype et prototypes : encore une affaire de famille. In D. Dubois (Ed.), Sémantique et cognition (pp. 103-129). Paris : CNRS-Editions. https://doi.org/10.4000/ rechercheformation.

Leblanc, S. (2014). Vidéo formation et transformations de l'activité professionnelle. Activités, 11(2). https://doi.org/10.4000/activites.968

Leblanc, S. (2015). Expériences mimétiques en Vidéo formation et transformation de l'activité professionnelle. Recherche et Formation, 75, 37-50.

Leblanc, S. (2018). Analysis of Video-Based Training Approaches and Professional Development. Contemporary Issues in Technology and Teacher Education, 18(1), 125-148.

Leblanc, S., \& Blanes-Maestre, C. (2018). Immersion, réflexion, imagination et transformation via le visionnement de vidéos d'enseignants. In C. Gaudin, S. Moussay, S. Flandin, \& S. Chalies (Eds.), Vidéoformation et développement de l'activité professionnelle enseignante (pp. 65-94). Paris : L'Harmattan. 
Leblanc, S., Ria, L., Dieumegard, G., Serres, G., \& Durand, M. (2008). Concevoir des dispositifs de formation professionnelle des enseignants à partir de l'analyse de l'activité dans une approche enactive. Activités, 5(1), 58-78.

Leblanc, S., \& Sève, C. (2012). Vidéo formation et construction de l'expérience professionnelle. Recherche et Formation, 70, 47-60.

Maturana, H. R., \& Varela, F. J. (1994). L'arbre de la connaissance. Paris : Addison-Wesley.

Mollo, V. (2004). Auto- and Allo-confrontation as tools for reflective activities. Applied Ergonomics, 35 (6), 531-540.

Muller, A., \& Lussi Borer, V. (2018). Analyse de l'activité, environnement de vidéo-formation et développement professionnel des enseignants. Différences intra et inter-activités : Le possible, le réel et le virtuel. In C. Gaudin, S. Flandin, \& S. Moussay (Eds.), Vidéo-formation et développement de l'activité professionnelle enseignante (pp. 95-116). Paris : L'Harmattan.

Pastré, P. (2005). Apprendre par la simulation. De l'analyse du travail aux apprentissages professionnels. Toulouse : Octarès.

Petitmengin, C. (2006). Describing one's subjective experience in the second person. An interview method for the science of consciousness. Phenomenology and the cognitive sciences, 5, 229-269.

Poizat, G., \& Goudeaux, A. (2014). Appropriation et individuation : un nouveau modèle pour penser l'éducation et la formation ? TF-Refa, 12, 13-38. https://transformations.univ-lille.fr/ index.php/TF/issue/view/1 - https://riviste.unimc.it/index.php/es_s/article/view/708/488

Poizat, G., Salini, D. \& Durand, M. (2013). Approche énactive de l'activité humaine, simplexité et conception de formations professionnelles. Éducation, Sciences \& Society, 4(1), 97-112.https:// riviste.unimc.it/index.php/es_s/article/view/708/488

Poizat, G., \& San Martin, J. (2020). Le programme de recherche “ cours d'action » : repères historiques et conceptuels. Activités (sous presse).

Ria, L. (Ed.) (2010). Plateforme de formation en ligne Néopass@ction de l'Institution Français de l'Éducation de l'ENS de Lyon. http://neo.ens-lyon.fr/neopass

Ria, L., \& Leblanc, S. (2011). Conception de la plateforme de formation Néopass@ction à partir d'un observatoire de l'activité des enseignants débutants : Enjeux et processus. Activités, 8(2). https://doi.org/10.4000/activites.2618

Roche, L. \& Gal-Petitfaux, N. (2017). L'usage de la vidéo dans la formation des enseignants d'EPS : nouvelles perspectives d'usage. 7ème Biennale internationale de l'AFRAPS, Pratiques sportives, éducation physique et société numérique : de l'outil à la transformation des rapports au corps, aux autres, au temps et à l'espace, AFRAPS, novembre, Mérignac, France.

Rosch, E. (1973). Natural categories. Cognitive Psychology, 7, 328-350.

Saint Aubert (de), E. (2010). Espace et schéma corporel dans la philosophie de la chair de MerleauPonty. In A. Berthoz \& B. Andrieu (Eds.), Le Corps en Acte (pp. 125-152). Nancy : Presses Universitaires de Nancy.

San Martin, J. (2015). La culture d'action des enseignants de l'école primaire au Chili : contribution au développement d'une anthropologie énactive. Thèse de doctorat non publié, Toulouse, Université Toulouse II-Le Mirail.

Saury, J., Adé, D., Gal-petitfaux, N., Huet, B., Sève, C. \& Trohel,J. (2013). Actions, significations et apprentissages en EPS. Une approche centrée sur les cours d'expérience des élèves et des enseignants. Paris : EP\&S. 
Schaeffer, J.-M. (1999). Pourquoi la fiction? Paris : Seuil.

Schaeffer, J.-M. (2002). De l'imagination à la fiction. Vox-poetica. Consulté le 23 février 2020. http://www.vox-poetica.org/t/articles/schaeffer.html

Secheppet, M. (2020). Apprendre dans un environnement de formation réel et simulé :

Articulations d'expérience dans l'activité des cochers-meneurs d'attelage. Thèse de Doctorat, Montpellier, Université de Montpellier.

Sherin, M.G., Russ, R.S., Sherin, B.L., \& Colestock, A. (2008). Professional Vision in Action : An Exploratory Study. Issues in Teacher Education, 17(2), 27-46.

Terré, N., Sève, C. \& Saury, J. (2016). Une approche enactive du développement des compétences en milieu scolaire. Éducation et francophonie, $\operatorname{XLIV}(2), 68-85$.

Theureau, J. (2000). Anthropologie cognitive \& analyse des compétences. In J. M. Barbier (Ed.), L'analyse de la singularité de l'action (pp. 171-211). Paris : PUF.

Theureau, J. (2004). Le cours d'action : Méthode élémentaire. Toulouse : Octarès.

Theureau, J. (2006). Le cours d'action : Méthode développée. Toulouse : Octarès.

Theureau, J. (2009). Le cours d'action : Méthode réfléchie. Toulouse : Octarès.

Theureau J. (2011). L'observatoire des cours d'action, des cours de vie relatifs à une pratique et de leurs articulations collectives. In G. Le Meur \& M. Hatano (Eds.), Approches pour l'analyse des activités (pp. 23-76). Paris : L'Harmattan.

Theureau, J. (2015). Le cours d'action : L'enaction \& l'expérience. Toulouse : Octarès.

Varela, F. J. (1989). Autonomie et connaissance-essai sur le vivant. Paris : Seuil.

Wulf, C. (2007). Une anthropologie historique et culturelle rituels, mimésis sociale et performativité. Paris : Téraèdre.

\section{ANEXOS}

Anexos 
Anexo 1 : Atónita ante el ritmo fetal.

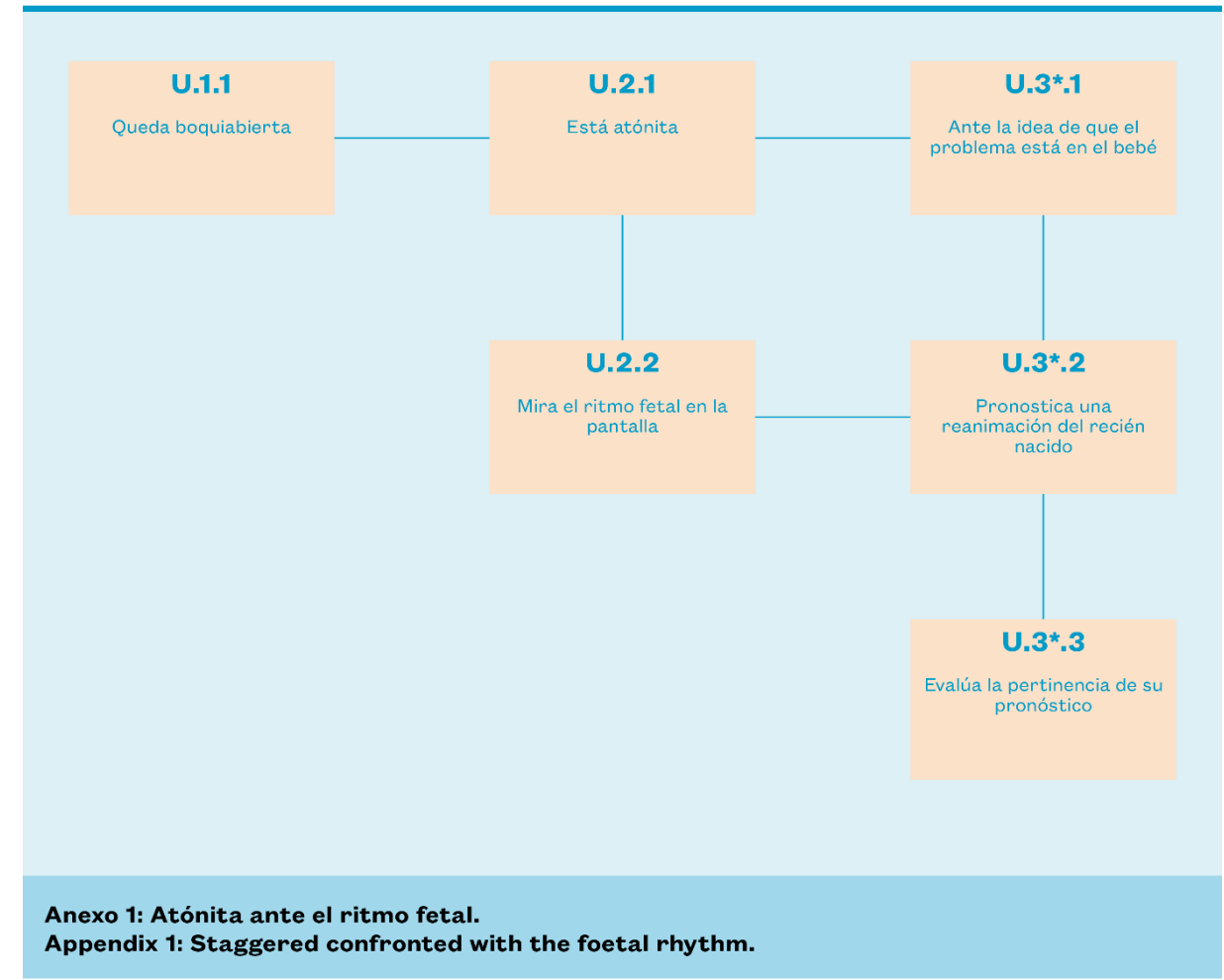

Anexo 1 : Atónita ante el ritmo fetal

Anexo 2 : Atónita ante el acondicionamiento de la mesa de reanimación.

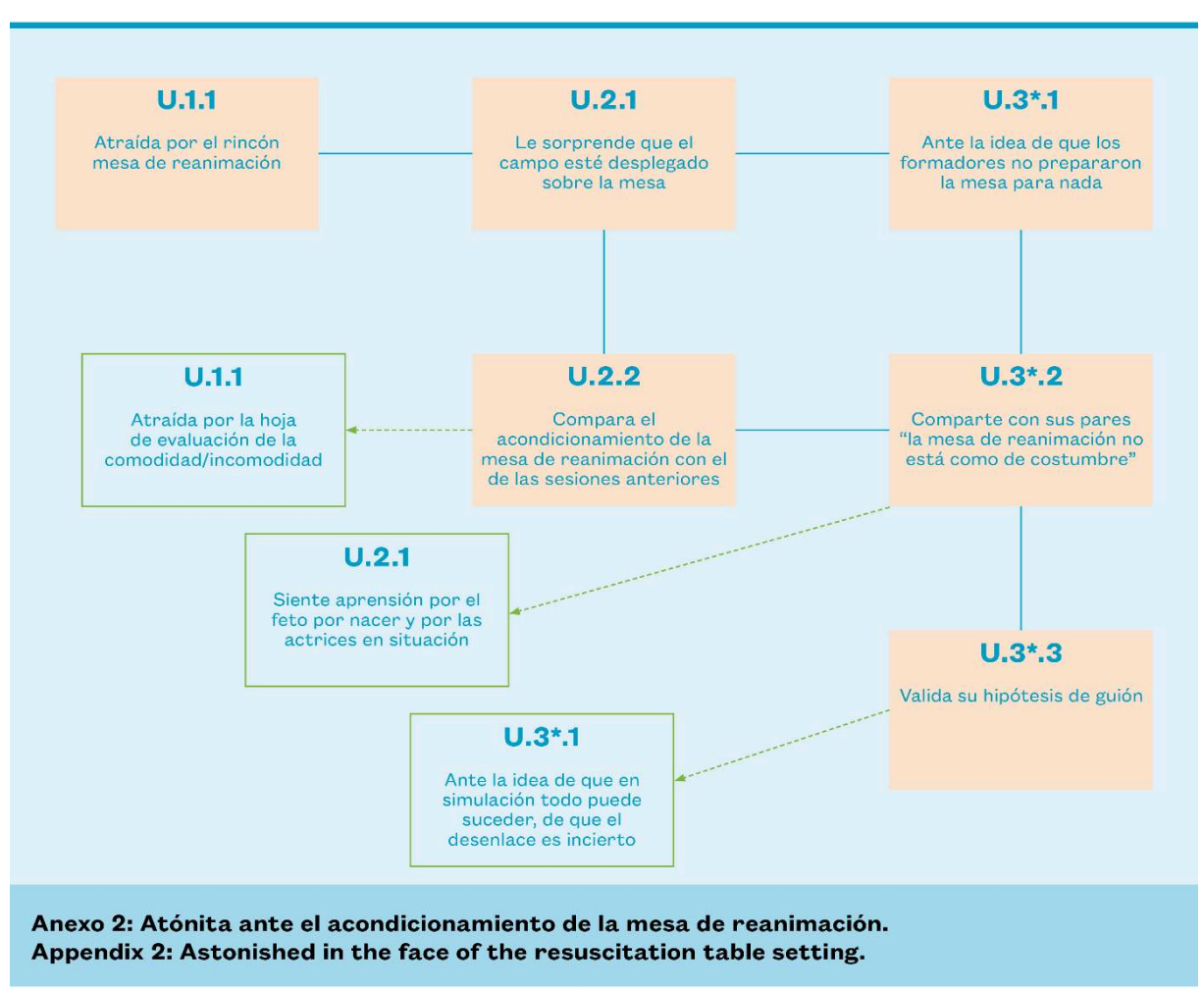

Anexo 2 : Atónita ante el acondicionamiento de la mesa de reanimación 
Anexo 3 : Siente la situación de malestar dei feto y de la partera

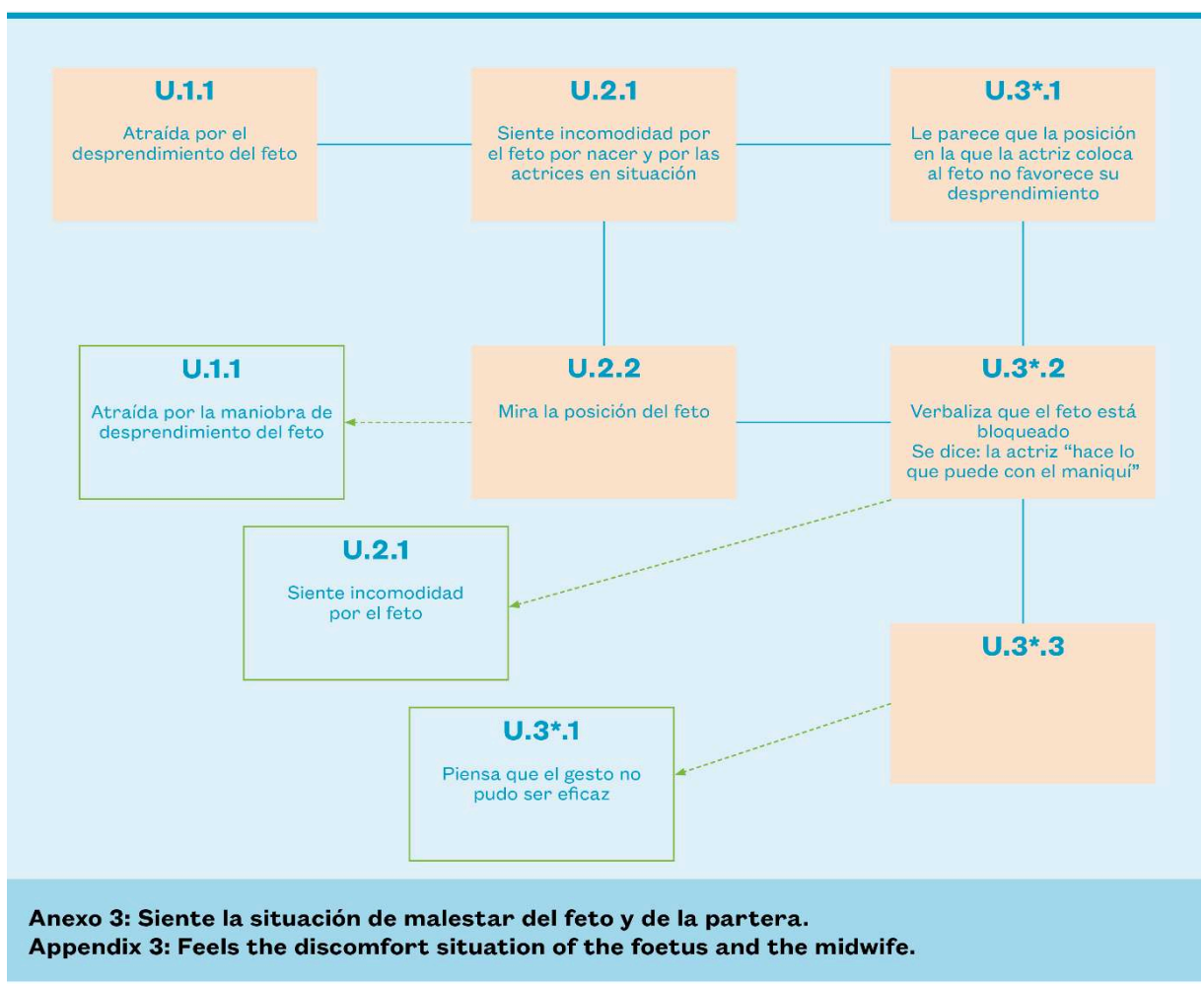

Anexo 3 : Siente la situación de malestar dei feto y de la partera

Anexo 4 : Realiza la maniobra de restitución

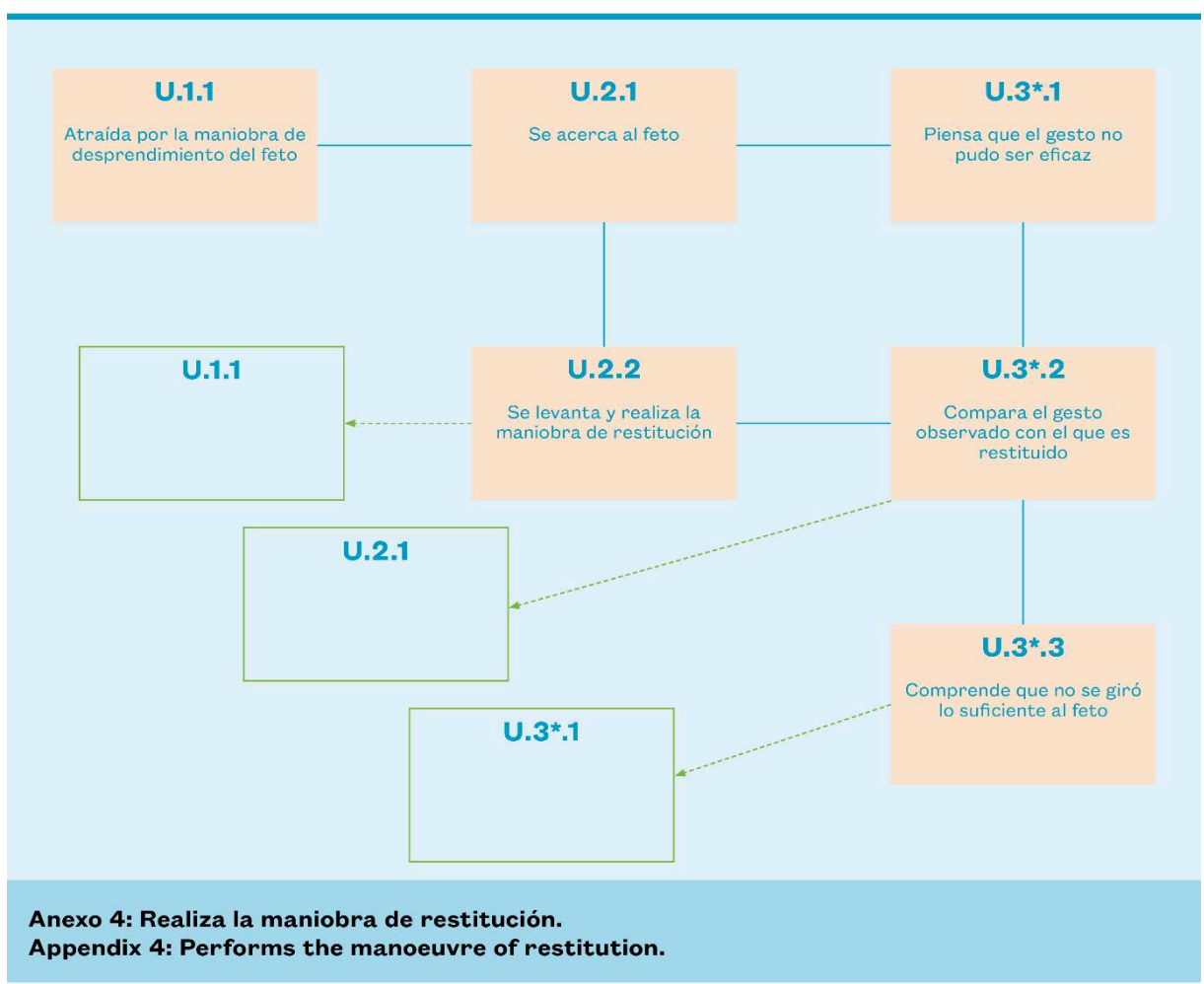

Anexo 4 : Realiza la maniobra de restitución 
Anexo 5 : Hexatomia de la U de un signo Investigación/ Historia/Pasión

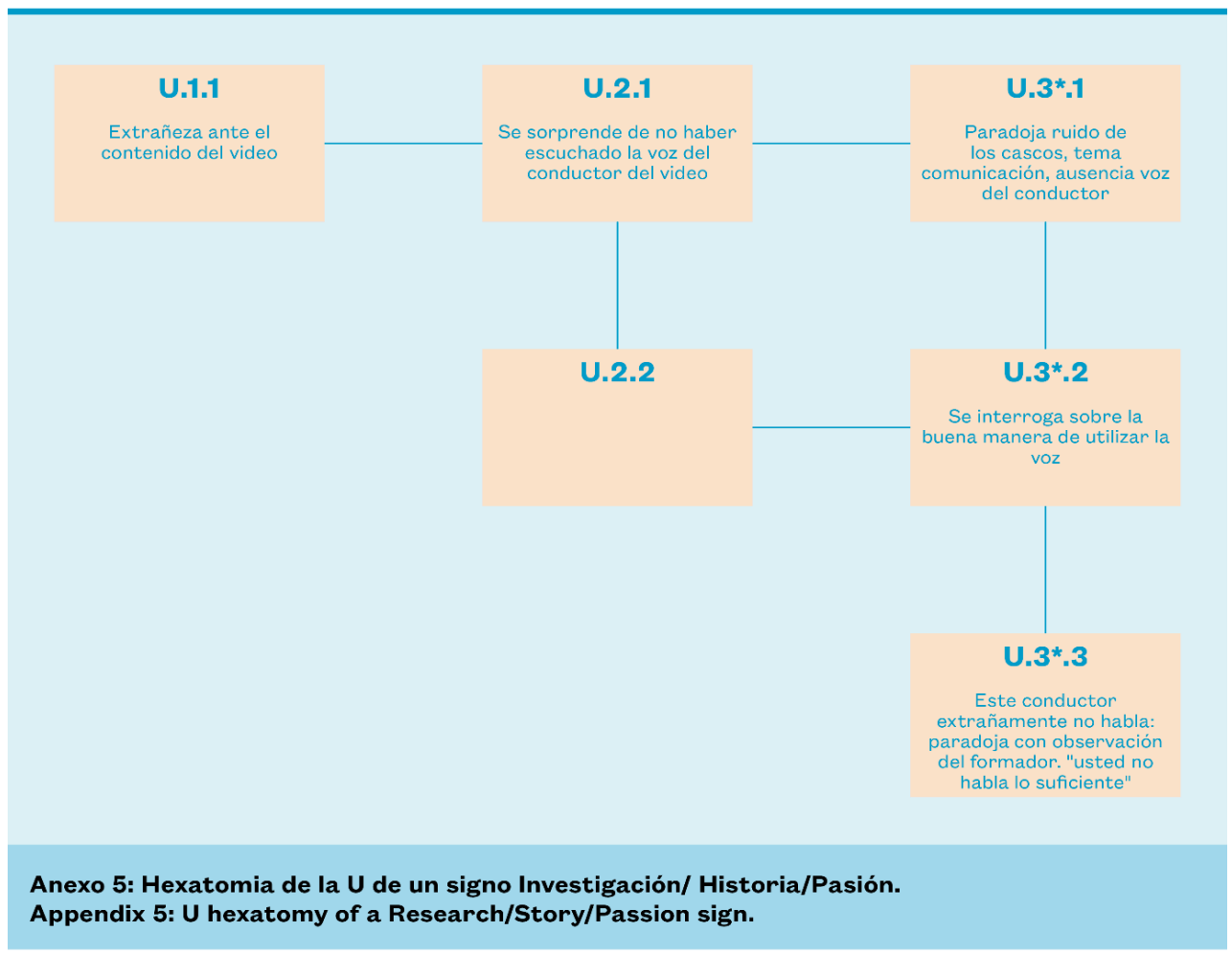

Anexo 5 : Hexatomia de la U de un signo Investigación/ Historia/Pasión

\section{NOTAS}

1. La aloconfrontación remite acá a una modalidad didáctico-pedagógica que consiste en poner a un estudiante en situación de observar la actividad de un par, con la finalidad de potenciar los aprendizajes. No se trata de un dispositivo metodológico que pueda prestarse para hacer una investigación (Mollo, 2004).

2. Según el programa de investigación curso de acción ( $\mathrm{CdA}$ ), se define a la actividad como cognitiva, autónoma, encarnada, situada dinámicamente en un mundo en el que existen otros actores, técnicamente constituida, cultivada y vivida (Theureau, 2006, p. 40).

3. Los tipos son el resultado de un proceso de tipicalización a través del cual una persona reconoce ciertas experiencias singulares como recurrentes en contextos percibidos como similares. Se describen como "esquemas típicos de atención, de percepción, de acción, de comunicación, de interpretación y de emociones" (Theureau, 2000, p. 185, traducción libre), siempre ligadas a la actividad en curso.

4. Esta doble dinámica funciona en ambos sentidos: algunas experiencias pasadas son convocadas durante la situación de aloconfrontación, algunas experiencias vividas en video-formación o simulación se movilizan en situación de práctica real.

5. Plataforma de video-formación que organiza huellas de actividad real de docentes obtenidas de extractos de filmaciones, fotos, entrevistas y que servirán como recursos para el desarrollo profesional (Ria, 2010). http://neo.ens-lyon.fr/neopass/connexion.php

6. La formación estudiada se refiere a la formación profesional de cocheros-conductores impartida por el Instituto Francés del Caballo y de la Equitación (IFCE). El certificado de especialización en "Utilización y conducción de carruajes" es un título del ministerio encargado 
de la agricultura que certifica una calificación profesional. El cochero-conductor utiliza caballos para transportar público o para realizar servicios agrícolas o de acondicionamiento. La formación prevé 126 horas de técnica con caballos enganchados, pero el número de horas de conducción efectiva por pasante es mucho menor.

7. Dos nuevas herramientas pedagógicas enriquecieron el ámbito de formación: una plataforma de video-formación llamada Ercam y un simulador de guías interactivas llamado CoMtactS.

8. La noción de performatividad remite, según Wulf (2007, p. 93, traducción libre), "a la aptitud del cuerpo para construir un mundo" que "se expresa en la lengua y en el actuar social".

9. "Presentamos aquí el orden de construcción del investigador que no necesariamente es el del orden temporal de la práctica pues, en realidad, no hay un orden temporal, el signo hace aparecer esos componentes en un proceso global continuo" (Theureau, 2006, p. 289, traducción libre).

10. Dos tesis recientes, inscriptas en el marco del programa de investigación del curso de acción, fueron las primeras en aprovechar la utilización de las hexatomias de R, U e I para tratar un corpus de datos en relación con un objeto de estudio particular: la actividad de improvisación de docentes noveles (Azéma, 2015) y la cultura de acción de los docentes (San Martín, 2015).

11. La relación con un nuevo elemento del signo transforma los elementos precedentes. Ejemplo: la relación E-R transforma E en E' (Theureau, 2006, p. 282).

12. Relación ordenada entre procesos: el proceso posterior depende para su existencia del proceso anterior (lo que significa, por ejemplo, que si observo un [U.2.2] es que los [U.1.1] [U.2.1] [U.3*.1] lo sucedieron). Relación "en un trasfondo de" $\rightarrow$ (Theureau, 2006, p. 282).

13. Los gestos "icónicos" reproducen por lo menos parcialmente los gestos actuales o la forma o el movimiento de un objeto, o indican su locación espacial (por ejemplo, la mímica del movimiento de golpear un obstáculo cuando el actor relata la experiencia de un accidente) (Petitmengin, 2006, p. 247).

14. "Llamada acción simbólica (es decir acompañada de un discurso privado, y que puede reducirse a una imaginación acompañada de un discurso privado o incluso reducirse a simplemente un discurso, que constituyen acciones del actor sobre sí mismo) o comunicación" (Theureau, 2006. p. 286, traducción libre).

15. Según Henriot (1983), la característica más evidente de la conducta lúdica es que la acompaña un margen de imprevisibilidad: actuar es no saber hacia dónde se va. La actitud lúdica es también hacer como si la situación simulada fuera real (ilusión) y separarse del mundo en el que tuvo su origen (duplicidad) para sumergirse y experimentar una situación diacrónica, compuesta de secuencias práxicas más o menos aleatorias cuyas consecuencias serán irreversibles.

16. Esos resultados evocan los producidos en una investigación que estudia un diálogo de autoconfrontación cruzada entre obreros del sector de la construcción (Duboscq \& Clot, 2010). En la auto-confrontación cruzada, los obreros hacen nuevos gestos para probar. Para los investigadores, esos gestos, después de haber sido utilizados como "instrumentos de argumentación y de análisis" sirven "como instrumento práctico" (Ibid, p. 280, traducción libre).

17. Roche y Gall-Petitfaux (2017) estudiaron diferentes situaciones de visualización en un contexto de formación multimodal en EPS (Éducation physique et sportive) con videos tomados a partir de diferentes planos: gran angular, 360, integrado y video sincronizado (plano integrado y plano en gran angular montados en el mismo video). Sus resultados confirman que la visualización de video de tipo integrado genera en la clase una experiencia de inmersión (Sherin, Russ, Sherin, \& Colestock, 2008).

18. El término degradada, en el caso de la unidad de experiencia que es de la categoría de lo Actual, significa que se le asocia una característica que la remite a una categoría de lo Potencial. Se tiene pues un Actual Potencial o un Actual de contornos poco determinados.

19. El desarrollo de las competencias estaría vinculado a una permanencia del compromiso de los actores que investigan y tratan de establecer relaciones entre distintas experiencias en el seno de 
historias (Terré, Sève, \& Saury, 2016). "Es involucrándose en historias como las acciones y las interpretaciones de los alumnos toman espesor temporal y como ellos construyen "disposiciones para actuar" (Durand, 2013) constitutivas de competencias" (Terré, Sève, \& Saury, 2016, p. 81, traducción libre).

20. Un estudio realizado en el marco de la clínica de la actividad ha mostrado que la repetición de las situaciones intersubjetivas de observación asociadas al método de auto-confrontación cruzada permitía "construir objetividad al redefinir entre los profesionales un perímetro dialógico que no habían imaginado” (Bonnemain, Perrot, \& Kostulski, 2015, p. 121, traducción libre).

\section{RESÚMENES}

Este artículo presenta una reflexión teórica para estudiar los procesos de aprendizaje-desarrollo que se ponen en marcha en contextos de formación que deliberadamente hacen que los participantes de ésta se enfrenten al mundo del otro. Esos contextos, concebidos a partir de filmaciones de trabajo real o de la observación en una situación de simulación y/o de prácticas acompañadas, requieren de la articulación de procesos miméticos, reflexivos, proyectivos y lúdicos. Durante el período 2011-2020, en el marco del programa de investigación empírica llamado "Curso de acción" o de "antropología cultural enactiva", se llevaron a cabo tres estudios relativos a situaciones de video-formación y/o de simulación en ámbitos profesionales diferentes (formación de docentes, de matronas y de conductores de carruajes). Para dar cuenta de esos procesos de mímesis social silenciosos y complejos que ponen en relación experiencias vividas por los actores (inmersión, imitación, emulación, hacer lo mismo, representación, anticipación), se desarrolló una modelización teórica. Esta reducción teórica basada en la hexatomia de la unidad de acción abre pistas metodológicas que permiten al mismo tiempo, captar mejor las dimensiones implícitas de la actividad corporal y sensible muy presentes en esa relación con el mundo del otro y, a la vez, comprender mejor las condiciones de performatividad de la acción (mímesis como repetición creativa vs mimetismo como copia de lo real).

Este artigo apresenta uma reflexão teórica para estudar os processos de aprendizagemdesenvolvimento no trabalho em ambientes de formação que confrontam intencionalmente o formando com o mundo dos outros. Estes ambientes, concebidos a partir de filmes de trabalho real ou de observação em situação de simulação e/ou práticas acompanhadas, exigem a articulação de processos miméticos, reflexivos, projetivos e lúdicos. Durante o período 2011-2020, foram realizados três estudos relativos a situações de formação em vídeo e/ou simulação em diferentes áreas profissionais (formação de professores, parteiras, chefes de equipa) no quadro de um programa de pesquisa empírica conhecido como o "Curso de ação" ou de "antropologia cultural ativa". Um modelo teórico foi desenvolvido para dar conta desses processos silenciosos e complexos de mimese social que ligam experiências vividas pelos atores (imersão, imitação, emulação, ser semelhante, representação, antecipação). Essa redução teórica baseada na hexatomia da unidade de ação abre pistas metodológicas que permitem compreender melhor as dimensões implícitas da atividade corporal e sensível, muito presentes nessa relação com o mundo dos outros, e, ao mesmo tempo, compreender melhor as condições de performatividade da ação (mimese como recuperação criativa vs mimetização como cópia da realidade). 
Cet article présente une réflexion théorique pour étudier les processus d'apprentissagedéveloppement à l'œuvre dans des environnements de formation qui confrontent intentionnellement les formés au monde d'autrui. Ces environnements conçus à partir de films du travail réel ou à partir d'observation en situation de simulation et/ou de pratiques accompagnées, sollicitent l'articulation de processus mimétiques, réflexifs, projectifs et ludiques. Au cours de la période 2011-2020, trois études relatives à des situations de vidéoformation et/ou de simulation dans des domaines professionnels différents (formation d'enseignants, de sagesfemmes, de meneurs d'attelage de chevaux) ont été conduites dans le cadre du programme de recherche empirique dit du "Cours d'action" ou d"' anthropologie culturelle enactive ». Une modélisation théorique a été développée pour rendre compte de ces processus de mimésis sociale silencieux et complexes de mises en relation d'expériences vécues par les acteurs (immersion, imitation, émulation, faire le semblable de, représentation, anticipation). Cette réduction théorique basée sur l'hexatomie de l'unité d'action ouvre des pistes méthodologiques à la fois pour mieux saisir les dimensions implicites de l'activité corporelle et sensible très présentes dans ce rapport au monde d'autrui et, en même temps, permet de mieux comprendre les conditions de performativité de l'action (mimésis comme reprise créative vs mimétisme comme copie du réel).

This paper presents a theoretical reflection to study the processes of work learning and development proceeding in the training environments which intentionally bring together the trainees to other people's world. These environments are built up from movies of real work or from observations in simulating and/or supported practices situations. These environments seek articulation between mimetic, reflexive, projective and ludic processes. Over the 2011-2020 period, three studies regarding video-training and/or simulation situations in various professional fields (teachers, midwifes and carriage drivers training) have been led within the framework of the empirical research program known as the "Course of action" or "enactive cultural anthropology". A theoretical modelling has been developed to account for these silent and complex social mimesis processes of linking agents experiences (immersion, imitation, emulation, "acting similarly to", representation, anticipation). This theoretical reduction based on the hexatomy of the course of action unit opens up some methodological paths to both better comprehend the implicit dimensions of body and sensitive activity, very active in this relation to other's world, and to better understand the performativity conditions of action (mimesis as a creative remake vs mimesis as a copy of reality).

\section{ÍNDICE}

Mots-clés: expérience mimétique, vidéo-formation, simulation haute-fidélité, alloconfrontation, cours d'expérience

Palabras claves: experiencia mimética, video-formación, simulación en alta fidelidad, aloconfrontación, curso de la experiencia

Palavras-chave: experiência mimética, formação em vídeo, simulação de alta fidelidade, alloconfronto, curso de experiência

Keywords: mimetic experience, video-training, high fidelity simulation, allo-confrontation, course of experience 


\section{AUTORES}

\section{SERGE LEBLANC}

LIRDEF EA3749 UM UPVM, Université de Montpellier - 163 rue Auguste Broussonnet - 34090 Montpellier

serge.leblanc@umontpellier.fr

\section{HÉLÈNE BOUCHOT}

LIRDEF EA3749 UM UPVM, Université de Montpellier - 163 rue Auguste Broussonnet - 34090 Montpellier

helene.bouchot@umontpellier.fr

\section{MÉLANIE SECHEPPET}

LIRDEF EA3749 UM UPVM, Université de Montpellier - 163 rue Auguste Broussonnet - 34090 Montpellier

melanie.secheppet@umontpellier.fr 